\title{
A taxonomic revision of Desmodesmus serie Desmodesmus (Sphaeropleales, Scenedesmaceae)
}

\author{
Eberhard HegEwALD ${ }^{1} \&$ Anke BRABAND ${ }^{2}$
}

${ }^{1}$ Grüner Weg 20, D-52382 Niederzier, Germany

${ }^{2} L C G$, Ostendstr. 25, D-12451 Berlin, Germany

\begin{abstract}
The revision of the serie Desmodesmus, based on light microscopy, TEM, SEM and ITS2r DNA, allowed us to distinguish among the taxa Desmodesmus communis var. communis, var. polisicus, D. curvatocornis, D. rectangularis comb. nov., D. pseudocommunis n. sp. var. texanus $\mathrm{n}$. var. and f. verrucosus $\mathrm{n}$. f., D. protuberans, D. protuberans var. communoides var. nov., D. pseudoprotuberans n. sp., D. schmidtii n. sp. Keys were given for light microscopy, electron microscopy and ITS2r DNA.
\end{abstract}

Key words: Desmodesmus, morphology, cell wall ultrastructure, cell size, ITS-2, new Desmodesmus taxa, phylogeny, taxonomy, variability

\section{INTRODUCTION}

Members of the former genus Scenedesmus s.l. were common in eutrophic waters all over the world. Hence taxa of that "genus" were described early in the $19^{\text {th }}$ century (e. g. TuRPIN 1820; 1828; MEYEN 1828; EHRENBERG 1834; CORDA 1835). Several of the early (before 1840) described taxa were insufficiently described and hence were often misinterpreted by later authors, especially the name $S$. quadricauda (TURPIN) BRÉB. was used for nearly every spiny "Scenedesmus" species (Hegewald 1979). In Scenedesmus s. 1. morphological very different taxa were included: ovate or spindle-like cells with or without spines. Therefore the "genus" was subdivided e. g. by CHODAT (1926) and more recently by HEGEWALD (1978), who recognized three subgenera. These were later elevated to genera. Based on DNA studies the subgenus Desmodesmus was raised to genus rank (AN et al. 1999) and based on morphological characteristic (spindle-like cells) the subgenus Acutodesmus was elevated to genus level by Tsarenko et Petlevanny (2001). The species with obtuse cells but without spines and cell wall ultrastructure were left over and belong to Scenedesmus s. str. (Hegewald et al. 1988). While the genus Desmodesmus was verified by VAN HANNEN et al. (2002), the genus Acutodesmus appeared to be polyphyletic (HEGEWALD \& Wolf 2003) and was later accepted by HegEwald et al. (2010) although splitting the genus Pectinodesmus. HEGEWALD et al. (2013) separated additionally the genera Chodatodesmus E.Hegewald and Verrucodesmus
E.Hegewald. Acutodesmus became recently a synonyme of Tetrades- mus (Wynne \& Hallan 2016).

The subsection Desmodesmus as described by Hegewald (1978) was best characterized by the cell wall ultra-structure which consists of an outer cell wall layer with net-like structure, lifted by tubes (PICKETTHeaps \& Staehelin 1975; KomÁReK \& Ludvík1972; Hegewald 1978, 1997) and rosettes covered or surrounded by tubes. The cells were linearly arranged in 2-8 celled coenobia, single cells were never produced. The cell shape was variable as also the spination, however, a quadricaudate spination was predominant, in some taxa additional spines or coenobia without spines were observed.

The subsection Desmodesmus included two series: Desmodesmus with the species D. communis (E. Hegewald) E. Hegewald) and D. protuberans (F.E. Fritsch et M.F.Rich) E.Hegewald as the here newly described taxa and the serie Maximi with the species D. maximus (W. et G. S. West) E.Hegewald, D. perforatus (Lemmerm.) E.Hegewald and D. tropicus (CROW) E.Hegewald. Both series differed by the type of rosettes, which were covered by tubes in the serie Desmodesmus and surrounded by tubes in the serie Maximi (KomÁrek \& Ludvík 1972; Hegewald \& Schnepf 1979). In the subsection Desmodesmus are the largest species of the genus Desmodesmus are recorded: $D$. maximus according to type description up to $36 \mu \mathrm{m}$ (serie Maximi) and D. protuberans and D. communis var. polisicus P.M.TSARENKo et E.Hegewald (both up to $34 \mu \mathrm{m}$ ) (serie Desmodesmus). 
The type of the section and subsection Desmodesmus was the Scenedesmus quadricauda CHOD. $\quad(=D$. communis (E.Hegewald) E.Hegewald (Hegewald 1978). The Scenedesmus (Desmodesmus) communis E.Hegewald was based on "Scenedesmus quadricauda ChODAT et auct. plur. p.p. an BRÉB." (CHODAT 1926) but not on S. quadricauda (TURPIN) BRÉB. The Desmodesmus communis differed from the Scenedesmus quadricauda significantly as was discussed by HEGEWALD (1977). COMPÈRE \& KomÁReK (1990) recommended the conservation of that name, which was done recently by conserving only the name and author of Achnanthes quadricauda TURPIN (= Scenedesmus quadricauda (TuRPIN) BRÉB.) (TurPIN 1828) but excluding its type (description or illustration) as also the first publication of that species (TURPIN 1820), hence thus producing a nomen nudum which was filled with the type description and type illustration of Scenedesmus (Desmodesmus) communis, which was already validly published in 1977 (Greuter et al. 2000). A not acceptable treatment. The correct citation should be Achnanthes quadricauda TURPIN sensu ICBN 2000 nom. illeg. because based on the type of Scenedesmus communis (HEGEWALD 1977).

Preliminary work for a revision of the section was done by Hegewald \& Schnepf (1979) and HegeWALD (1997). A recent revision of serie Maximi was done by Jeon \& Hegewald (2006). Hegewald (1984) reported on high temperature tolerating strains of the section. The studied species of the subsection Desmodesmus had high temperature tolerating strains and no high temperature tolerating strains, but if isolated from tropical climatic zones the strains were mainly tolerating high temperatures.

DNA studies for the subsection were first done by Paschma \& Hegewald (1986), the ITS-2r DNA was analyzed for D. communis by KITSCHKE (2001, alignment unpubl.), Hegewald et al. (2001) and Bica et al. (2012). Complete18S DNA was available only for $D$. communis (KESSLER et. al. 1997).

We studied the taxa Desmodesmus communis (86 strains), D. rectangularis (10 strains), D. communis var. curvatocornis (2 strains), D. pseudocommunis (3 strains), D. pseudocommunis f. verrucosus (1 strains), D. pseudocommunis var. texanus (1 strains), D. pseudoprotuberans (2 strains), D. protuberans (5 strains), $D$. protuberans var. communioides (9 strains) and $D$. schmidtii (2 strains) (Table S1). D. communis var. polisicus described by TSARENKO et al. (2006) was not restudied here.

Although the species of that subsection were common in nature, they were rare in the strain collections (e. g. ACOI: 6 strains sub nom. Scenedesmus communis and S. smithii, AICB: 6, CCAP: 1, now after uptake of our strains: 34 and SAG: 1). A few strains of collections formerly identified as "Scenedesmus quadricauda" are misidentified taxa belonging to the Desmodesmus armatus group (HEGEWALD 1982; HeGEWALD
1989; Hegewald et al. 2005) or to D. maximus (strain collection UTEX) (HEGEWALD 1989).

\section{Material And Methods}

118 strains were studied, 22 of these were used for ITS-2 rDNA analyses (Tables S1, S2). Most of the strains were from the collection of the first author (including strains of An, Groenn, Holtmann, Jees Bai and StoJkovich), several of these were transferred to the collection CCAP (Oban, UK). Some strains were received from FeLFöLDI (Museum Budapest), HindÁK (private collection, Bratislava), SAG (strains collection Göttingen), ACOI (strain collection Coimbra, Portugal) and AICB (strain collection Romania).

The isolates were cultured in batch cultures, in a shaking-apparatus-and/or in aerated tubes. As nutrition the modified medium of Bourrelly (HEGEWALD et al. 1994) or occasionally Chu X (Venkataraman 1969), $0.2 \times$ N8 (Soeder et al. 1967) or Korn (KorN 1969) were used. The modified trace element solution and B vitamins as cited in Hegewald et al. (1994) were added to all media. The tubes were aerated with a $1 \% \mathrm{CO}_{2}$ /air mixture and cultured at $30^{\circ} \mathrm{C}$ (some additionally at 20,25 or $38^{\circ} \mathrm{C}$ ) and $16: 8 \mathrm{~h}$ light-dark cycle and diluted daily to an extinction of 0.02 at $\lambda=560 \mathrm{~nm}$. The light intensity was about $200 \mu \mathrm{mol} . \mathrm{m}^{-2} \cdot \mathrm{s}^{-1}$. The batch cultures and the shaken cultures (110 rotations per minute) were cultured at $21 \pm 1{ }^{\circ} \mathrm{C}$ at a light-dark cycle $16: 8 \mathrm{~h}$ at about $50 \mu \mathrm{mol} \cdot \mathrm{m}^{-2} \cdot \mathrm{s}^{-1}$. The shaken cultures were diluted 2 times all 5 days.

For the size measurements one inner cell of 20 coenobia was used and about 100 coenobia were used for measuring the spines.

For size measurement of the cell wall net structure we used a Zeiss Videoplan. For each culture type we measured 50 structures of 10 photos of two specimens, resulting in a total of 3000 measurements.

For the transmission electron microscope, empty cell walls were enriched by sedimentation or centrifugation (if not studied immediately, they were preserved with glutardialdehyde or formaldehyde), washed with distilled water, air dried and studied under the TEM with no further treatment or after shadow casting with $\mathrm{Au} / \mathrm{Pd}\left(30^{\circ}\right)$. For sectioning they were conserved with $1 \% \mathrm{KMnO}_{4}$.

For the scanning electron microscope the cells were fixed with glutardialdehyde or formaldehyde, dehydrated in acetone steps, critical-point dried and sputtered with gold.

The complete ITS-2 rDNA sequences were determined as described in Hegewald et al. (2001). The alignment editor of HePperLe (2002) was used.

The alignment for ITS2 was performed by hand according information on secondary structures (see also Figs S1-6) with a total of 235 bases in $D$. communis et var., $D$. curvatocornis, $D$. rectangularis and $D$. pseudocommunis) and 236 (D. pseudoprotuberans, D. schmidtii, D. protuberans et var.).

\section{Results}

We accepted the taxa Desmodesmus communis, its var. polisicus and D. curvatocornis comb. nov., D. rectan- 
gularis comb. nov. and D. protuberans. We described as new the taxa $D$. pseudocommunis, $D$. pseudocommunis var. texanus, $D$. pseudocommunis f. verrucosus, $D$. pseudoprotuberans, D. schmidtii and D. protuberans var. communioides. In Fig. 1 is given a synoptic overview on the studied taxa, their cell size data, morphology and electron microscopical cell wall structures.

\section{Accepted taxa}

Desmodesmus communis (E.Hegewald) E.HegEwald var. communis (Figs 1I, 2, 3)

A common species with wide range of cell length 9.0 $23.1 \mu \mathrm{m}$ (Tables 1,S2) but mainly stable cell wall ultrastructure (Figs 1, 3, 17c, d) and invariable ITS 2 data (GenBank: Table S1).

D. communis var. polisicus P.M.Tsarenko et E.Hegewald (Tsarenko et al. 2006) (Fig. 2C)

A taxon with larger cell length 21.8-34.2 $\mu \mathrm{m}$ (Ta- bles $1, \mathrm{~S} 2$ ) than $D$. communis, morphologically more resembling $D$. maximus. The cell wall ultrastructure is similar to D. communis and the variety had zero differences from D. communis var. communis. (GenBank: Table S1).

\section{D. curvatocornis (Proshk.-Lavr.) E.Hegewald} comb. nov. (Figs 1D, 4, 5)

Basionym: Scenedesmus curvatocornis ProshK.-Lavr. 1925, Trudy Khar'kovsk. Obšč. Isp. Prir. 50: 36, fig. 8.

Characterized by the short spines, often strongly curved and sporadically additionally short spine or spines one of the outer cells (Hegewald 1979; Yamagishi \& HeGEWALD 1998; TSARENKO et al. 2005). Strain Hegewald 1977-144 had scattered single tubes on the cell surface only visible under the EM. The net-like structure was regular and dense. The difference in ITS2 between the species and D. communis was zero (Fig. 21, Table S3).

Table 1. Synopsis of size measurements for all strains of the taxa of serie Desmodesmus and for D. maximus (serie Maximi).

\begin{tabular}{|c|c|c|c|c|}
\hline taxon & $\begin{array}{l}\text { cell length } \\
\text { ( } \mu \mathrm{m}) \\
\text { average }\end{array}$ & $\begin{array}{l}\text { cell length } \\
(\mu \mathrm{m}) \\
\min -\mathrm{max}\end{array}$ & $\begin{array}{l}\text { cell length } \\
\text { : cell width }\end{array}$ & $\begin{array}{c}\text { spine length } \\
(\mu \mathrm{m}) \\
\min -\mathrm{max}\end{array}$ \\
\hline D. communis & $9.6-19.3$ & $7.6-23.1$ & $2.5-3.5$ & $8.2-15.2$ \\
\hline var. polisicus & - & $21.8-34.2$ & - & - \\
\hline D. rectangularis & $14.4-16.8$ & $12.8-19.3$ & $2.9-3.3$ & $8.1-10.2$ \\
\hline D. curvatocornis & 23.5 & $18.3-28.1$ & 3.1 & $<1$ \\
\hline D. pseudocommunis & $14.5-15.8$ & $11.4-19.3$ & 2.9 & 15.2 \\
\hline var. texanus & 19.0 & $15.6-21.6$ & 2.7 & - \\
\hline f. verrucosus & $18.3-19.4$ & $15.2-25.7$ & 3.0 & - \\
\hline D. pseudoprotuberans & $16.1-18.3$ & $13.8-22.8$ & $2.7-3.5$ & - \\
\hline D. schmidtii & $8.6 / 11.8$ & $7.3-12.6$ & $2.8 / 3.2$ & - \\
\hline D. protuberans & $18.2-27.1$ & $15.0-31.7$ & $3.1-4.4$ & $10.7-21.2$ \\
\hline D. maximus & $20.0-31.8$ & $17.4-36.9$ & $2.5-3.7$ & - \\
\hline
\end{tabular}

Table 2. Compensatory base change (CBC) in section Desmodesmus compared with strains of section Maximus and with D. pirkollei as outgroup.

\begin{tabular}{|c|c|c|c|c|c|c|c|c|c|c|c|c|}
\hline & & 1 & 2 & 3 & 4 & 5 & 6 & 7 & 8 & 9 & 10 & 11 \\
\hline 1 & D. pirkollei SAG2042 & 0 & 8 & 8 & 8 & 8 & 10 & 4 & 4 & 4 & 4 & 4 \\
\hline 2 & D. maximus Hegewald 1980-48 & 8 & 0 & 0 & 1 & 1 & 2 & 3 & 3 & 4 & 4 & 4 \\
\hline 3 & D. maximus UTEX 614 & 8 & 0 & 0 & 1 & 1 & 2 & 3 & 3 & 4 & 4 & 4 \\
\hline 4 & D. perforatus Hegewald 1997-12 & 8 & 1 & 1 & 0 & 0 & 1 & 3 & 3 & 5 & 4 & 4 \\
\hline 5 & D. tropicus Hegewald 1997-26 & 8 & 1 & 1 & 0 & 0 & 0 & 3 & 3 & 5 & 3 & 4 \\
\hline 6 & D. tropicus Hegewald 1998-18 & 10 & 2 & 2 & 1 & 0 & 0 & 5 & 5 & 6 & 5 & 5 \\
\hline 7 & D. communis Hegewald 1974-35 & 4 & 3 & 3 & 3 & 3 & 5 & 0 & 0 & 0 & 0 & 0 \\
\hline 8 & D. rectangularis Hegewald 1977-141 & 4 & 3 & 3 & 3 & 3 & 5 & 0 & 0 & 0 & 0 & 0 \\
\hline 9 & D. protuberans Hegewald 1997-2 & 4 & 4 & 4 & 5 & 5 & 6 & 0 & 0 & 0 & 0 & 0 \\
\hline 10 & D. pseudocommunis Hegewald 1976-43 & 4 & 4 & 4 & 4 & 3 & 5 & 0 & 0 & 0 & 0 & 0 \\
\hline 11 & D. pseudoprotuberans Hegewald 1981-51 & 4 & 4 & 4 & 4 & 4 & 5 & 0 & 0 & 0 & 0 & 0 \\
\hline
\end{tabular}




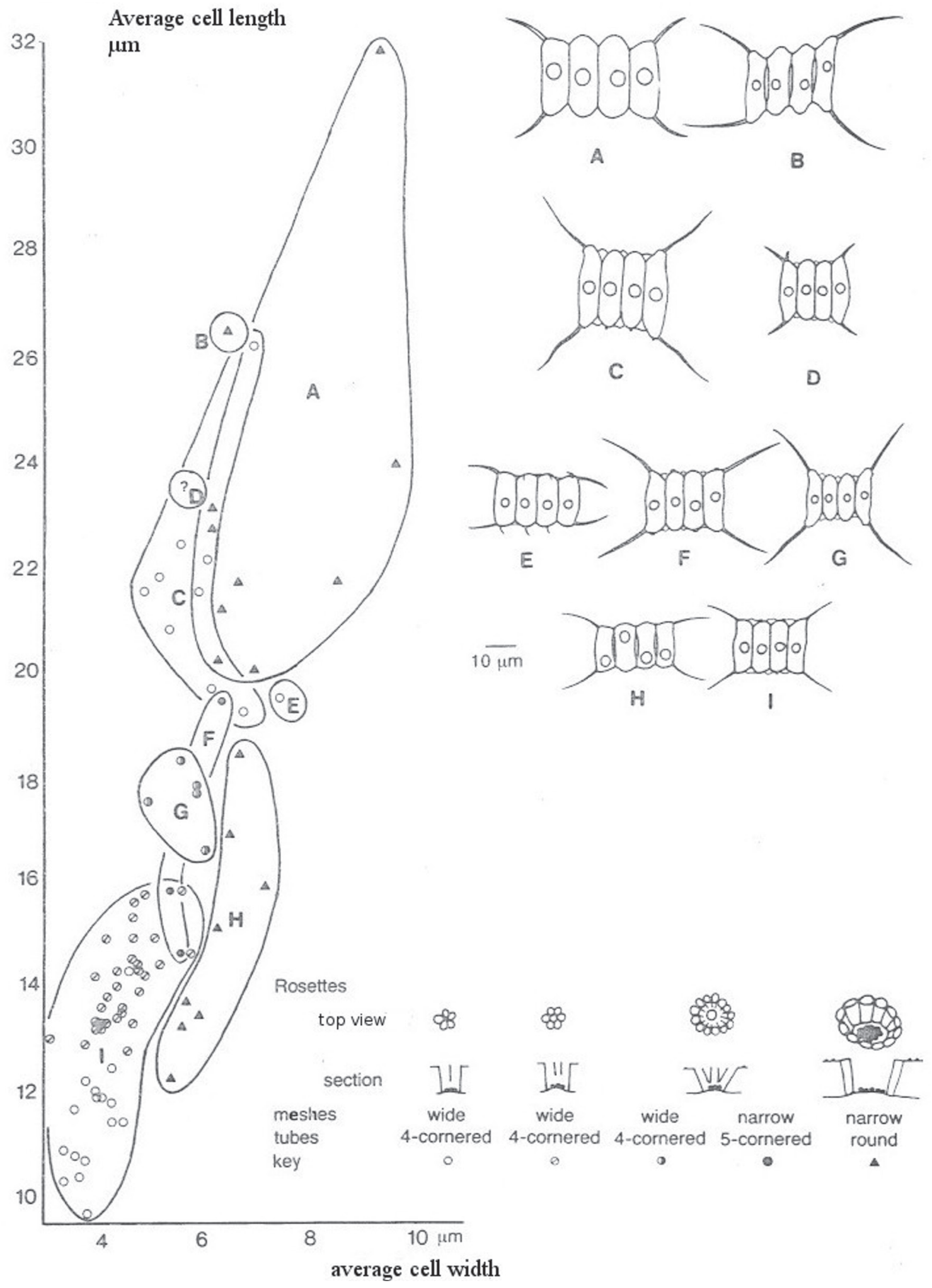

Fig. 1. Synoptical overview on the studied taxa of section Desmodesmus, cell size data (inner cells of coenobia), morphology and electron microscopic cell wall structures: (A) D. maximus; (B) D. tropicus; (C) D. protuberans; (D) D. curvatocornis; (E) D. rectangularis; (F) D. pseudocommunis; (G) D. pseudoprotuberans; (H) D. perforates; (I) D. communis. 


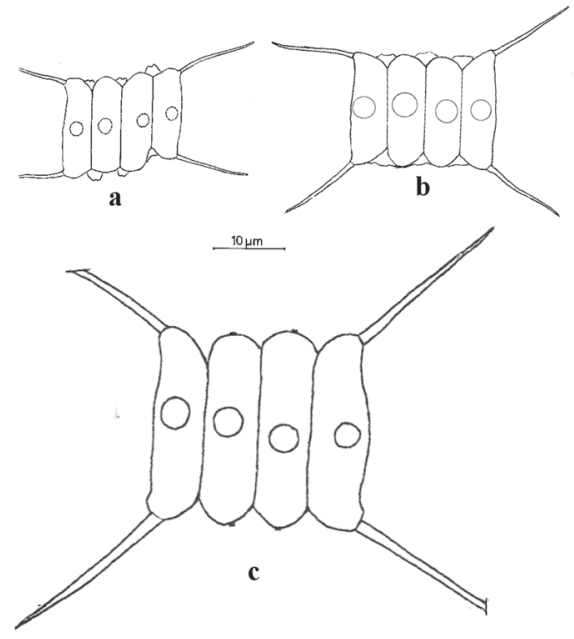

Fig. 2. Desmodesmus communis, light microscopic habitus: (a) small strain (Hegewald 1971-256, type strain); (b) large strain from Lake Titicaca, Peru (Hegewald 1977-170); (c) D. communis var. polisicus from TSARENKo et al. (2006).
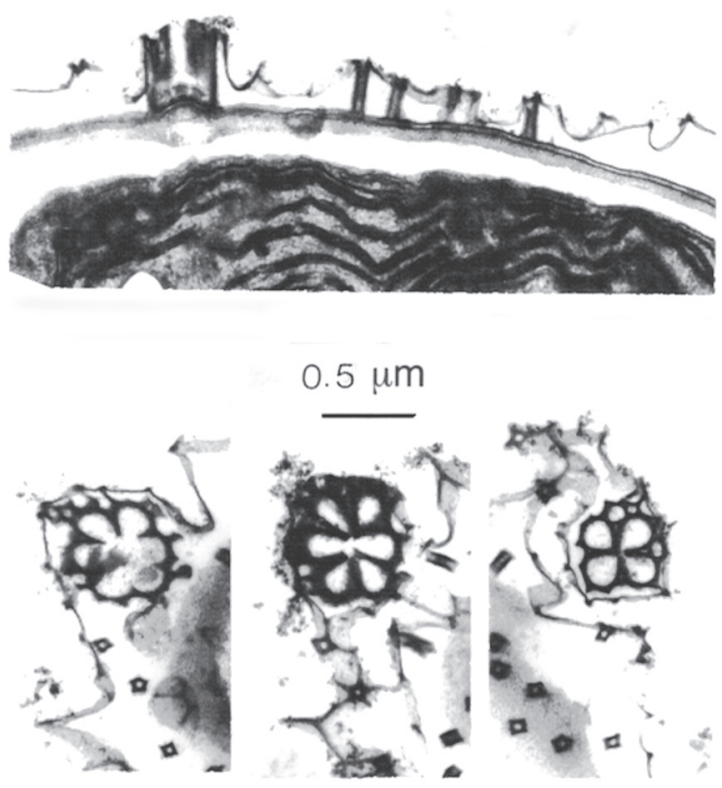

Fig. 3. Desmodesmus communis: (a) longitudinal section of a rosette; (b-d) serial section through a rosette basal to top (strain Hegewald 1975-135, India).

Although we weight ITS2 very high, the severe differences in morphology and cell wall ultrastructure forces us to keep the taxon at the level of a species (GenBank: Table S1). Cell size see Tables 1, S2.

\section{D. rectangularis (G.S.WeSt) E.Hegewald (Figs 1E, 6, 7)}

Basionym: Scenedesmus quadricauda var. rectangularis G.S.WEST 1914, Mem. Soc. Neuchátel. Sci. Nat. 5, 1025, pl. XXI, figs 14-21.

A species with slightly larger range of cell length than D. communis: $12.8-19.3 \mu \mathrm{m}$ (Tables 1, S2), cells are more compact with obtuse angel between cells and

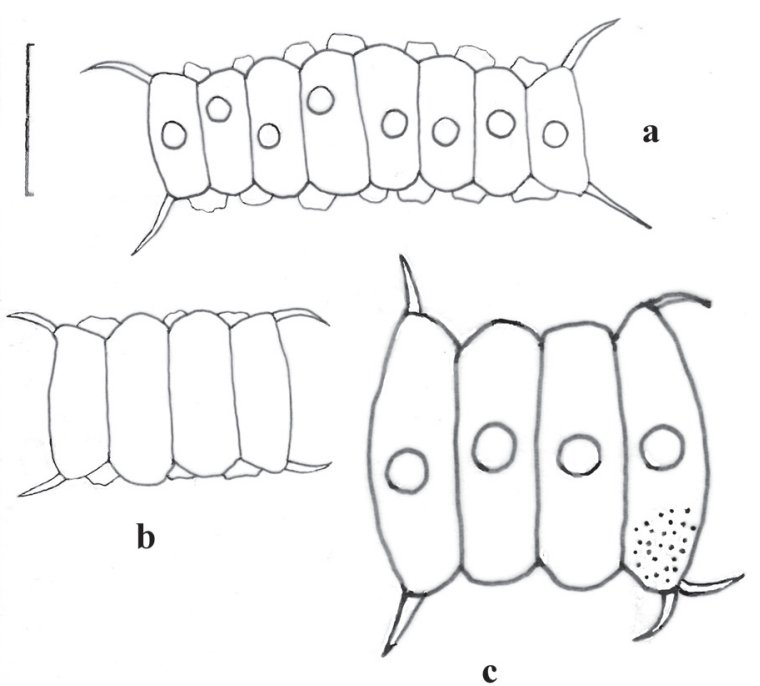

Fig. 4. Desmodesmus curvatocornis, light microscopic habitus: (a, b) strain Hegewald 1994-8; (c) specimen from Lake Steinhuder Meer (leg. Holtmann, 1977). Scale $10 \mu \mathrm{m}$.

usually additional spines on inner cells. Spines are as long as or often shorter than cell length. The cell wall ultrastructure as D. communis (Fig. 1) and in ITS 2 were two base exchanges compared to D. communis (Fig. S1). (GenBank: Table S1).

D. protuberans (F.E.Fritsch et M.F.RICH) E. HegeWALD (Figs 1C, 8a, b, S3)

Characterized by more elongated cells as well as by larger cell size (Tabs 1, S2) than the other members of the subsection Desmodesmus, and by longer outer cells than inner cells (except D. pseudoprotuberans), the smaller strains of the variety communioides (Figs $8 \mathrm{c}, \mathrm{d})$ were hardly to distinguish from $D$. communis. It differed in ITS2 from the other taxa discussed here by 5 to 7 base exchanges but the strains had a variability within themselves (Fig. S2). (GenBank: Table S1).

\section{Description of new taxa}

Desmodesmus pseudocommunis E. Hegewald sp. nov. (Figs 1F, 9a)

Description: cells $11.4-19.3 \times 4.1-6.4 \mu \mathrm{m}$ (strain Hegewald 1976-43). Rosettes wider than high. Net-like structure of outer cell wall layer had regular and smaller meshes than D. communis (Figs 1I, 9) GenBank access number KU359294 (ITS2).

Holotype: Fig. 9a.

Type strain: Hegewald 1976-43 (lost).

Paratype strains: Hegewald 1979-4 (Germany), Stojkovich 1998-2 (Serbia), AICB 1004 (Romania).

Type locality: Germany, Reservoir Halterner Stausee. Habitat: Reservoir.

Etymology: Morphological similarity with Desmodesmus communis. 

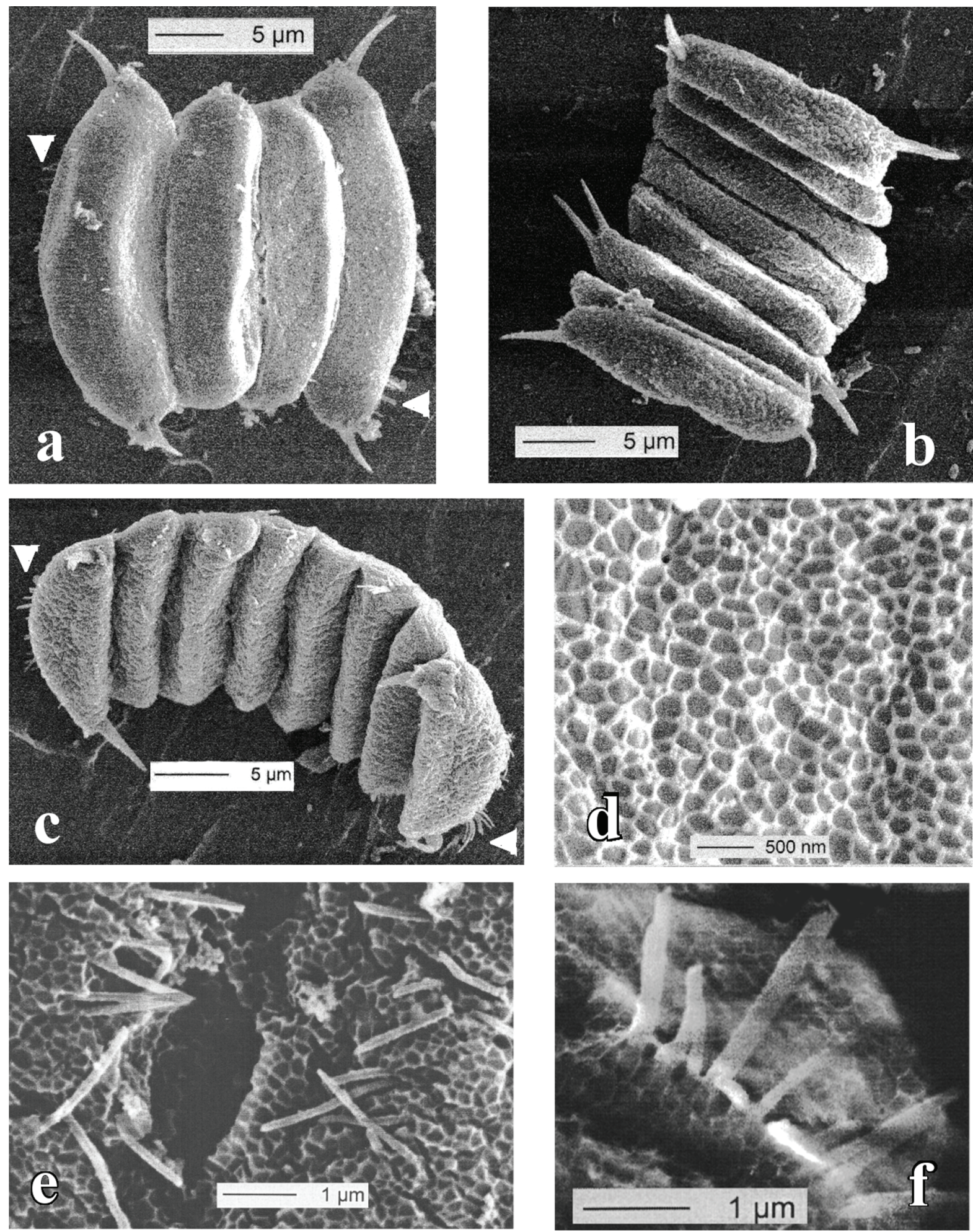

Fig. 5. Desmodesmus curvatocornis, strain Hegewald 1977-144 (strain from Lake Steinhuder Meer): (a) 4-celled coenobium (arrow heads in 5a and 5c: single tubes on the surface); (b) 8-celled coenobium with some additional spines; (c) 8-celled coenobium; (d) cell wall ultrastructure; (e) single tubes scattered on the surface; (f) single tubes and spines (bundles of tubes), arranged in a row.

Desmodesmus pseudocommunis var. texanus E. HEGEWALD var. nov. (Figs 10, 11)

Description: coenobia usually with four cells, quadricaudate or additionally on the lateral walls of outer and inner cells with short spines or short ribs. Cells 15.6-21.6 × 5.6-8.4 $\mu \mathrm{m}$ (average: $19.0 \pm 2.1 \times 7.2 \pm$
$0.9 \mu \mathrm{m})$. Outermost cell wall layer between cell poles often hardly visible. Rosettes wider than high. Bristles were freely produced.

Holotype: Fig 10.

Type strain: Hegewald 1986-24 (lost). 

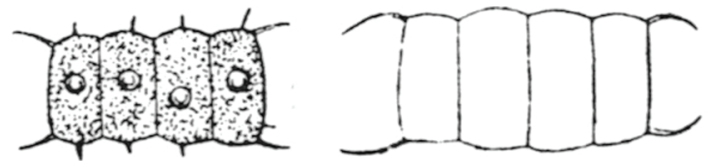

Fig. 6. Desmodesmus rectangularis, figs 16 and 18 of type figure (G.S.WEST 1914).

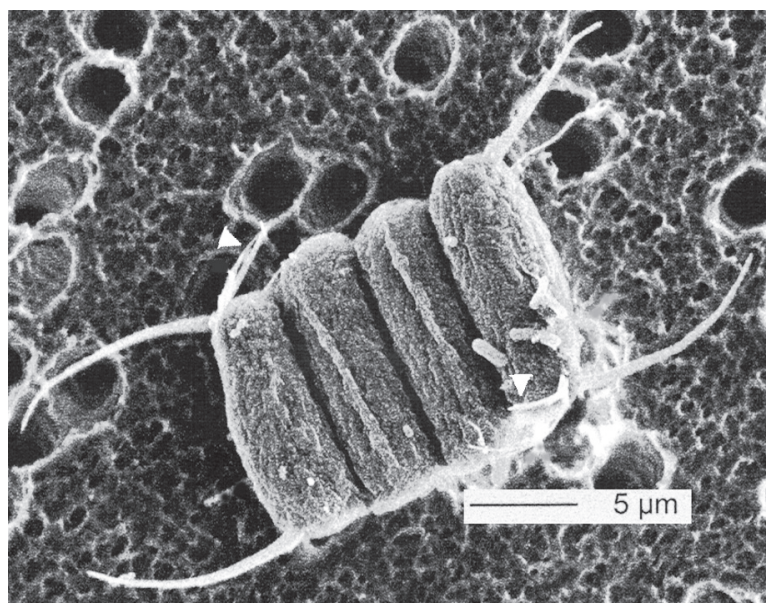

Fig. 7. Desmodesmus rectangularis, strain Hegewald 1977-141, habitus. Two arrow heads point to additional short spines.

Type locality: Lake Houston, Texas, USA.

Habitat: Plankton of a large Lake.

Etymology: The name was used because of the hitherto only known locality in the state of Texas.

Desmodesmus pseudocommunis f. verrucosus E. HEGEWALD f. nov. (Figs 9b, c, 12, 13)

Description: differs from Desmodesmus pseudocommunis f. pseudocommunis by size $(15.2-25.7 \mu \mathrm{m})$ and by groups of short tubes wider than the lifting tubes, scattered over the surface, visible only under the electron microscope.

GenBank access number KU359293(ITS2).

Holotype: Preserved sample of type strain (cultured in medium Pringsheim, harvested 4.7.1975), number B40 0041553 at herbarium of Botanical Garden and Botanical Museum, Berlin.

Type strain: Hegewald 1975-230 (lost).

Type locality: Lake Tegeler See, Berlin, Germany.

Habitat: Plankton of a stream lake.

Etymology: Name was given because of the granules which are visible under the electron mikroscope.

Remark: The invalid Scenedesmus quadricauda (var. obtusospinosus) f. heterogranulatus had some similarity especially fig. 1 of HorTobÁGYi (1971), and it was of similar size: 19.5-26 $\mu \mathrm{m}$. However, the name could not be used, because it was invalid.

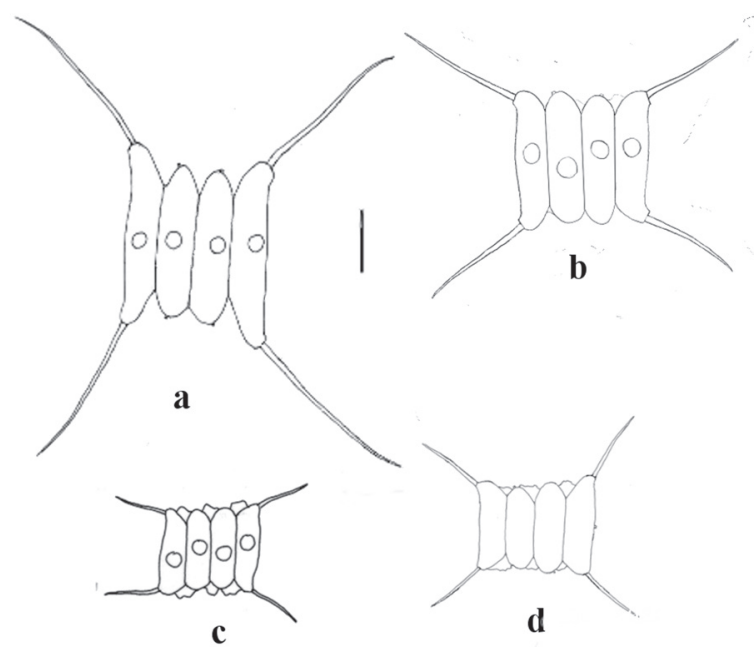

Fig. 8. Desmodesmus protuberans: (a-b) light microscopic habitus, (a) strain Hegewald 2001-4, (Germany, Berlin), (b) strain Hegewald 1979-6 (Germany, Dortmund), Desmodesmus protuberans var. communioides; (c) strain SAG 276/4b (UK, Cambridge); (d) strain Hegewald 1997-2 (Fiji). Scale $10 \mu \mathrm{m}$.

Desmodesmus pseudoprotuberans E. Hegewald sp. nov. (Figs 1G, 14-16)

Description: cells $12.0-22.8 \times 3.6-7.8 \mu \mathrm{m}$ (averages $14.0-18.3 \times 4.7-6.9 \mu \mathrm{m})$, outer cells somewhat longer than inner cells.

GenBank access number KU359303.

Holotype: Preserved sample of type strain (cultured in medium Pringsheim, harvested 22.5.1978), number B40 0041554 at herbarium of Botanical Garden and Botanical Museum, Berlin

Paratypes: Preserved sample of type strain (cultured in medium Pringsheim, harvested 23.3.1975), number B40 0041554 at herbarium of Botanical Garden and Botanical Museum, Berlin Dahlem.

Strain Hegewald 1981-51 (=CCAP 258/81) Reservoir Seletar, Singapore.

Type strain: Hegewald 1973-293, strain lost. Type locality: Lake Quistococha, Iquitos, Peru. Habitat: Plankton of a reservoir.

Etymology: Morphological similarity with Desmodesmus protuberans.

Remark: This rare taxon had apparently a tropical distribution.

Desmodesmus schmidtii E. Hegewald sp. nov. (Figs 17a,b, 18, 19)

Description: coenobia quadricaudate, bicaudate, heterocaudate or spineless. Cells in average 8.6/11.8 $\mu \mathrm{m}$ (two strains). Cell wall structures, rosettes and tubelike spacers were similar to those of $D$. communis but the number of spacers was greatly reduced and the netlike structure very delicate.

GenBank access number KU359297 (ITS2).

Holotype: Fig 19. 

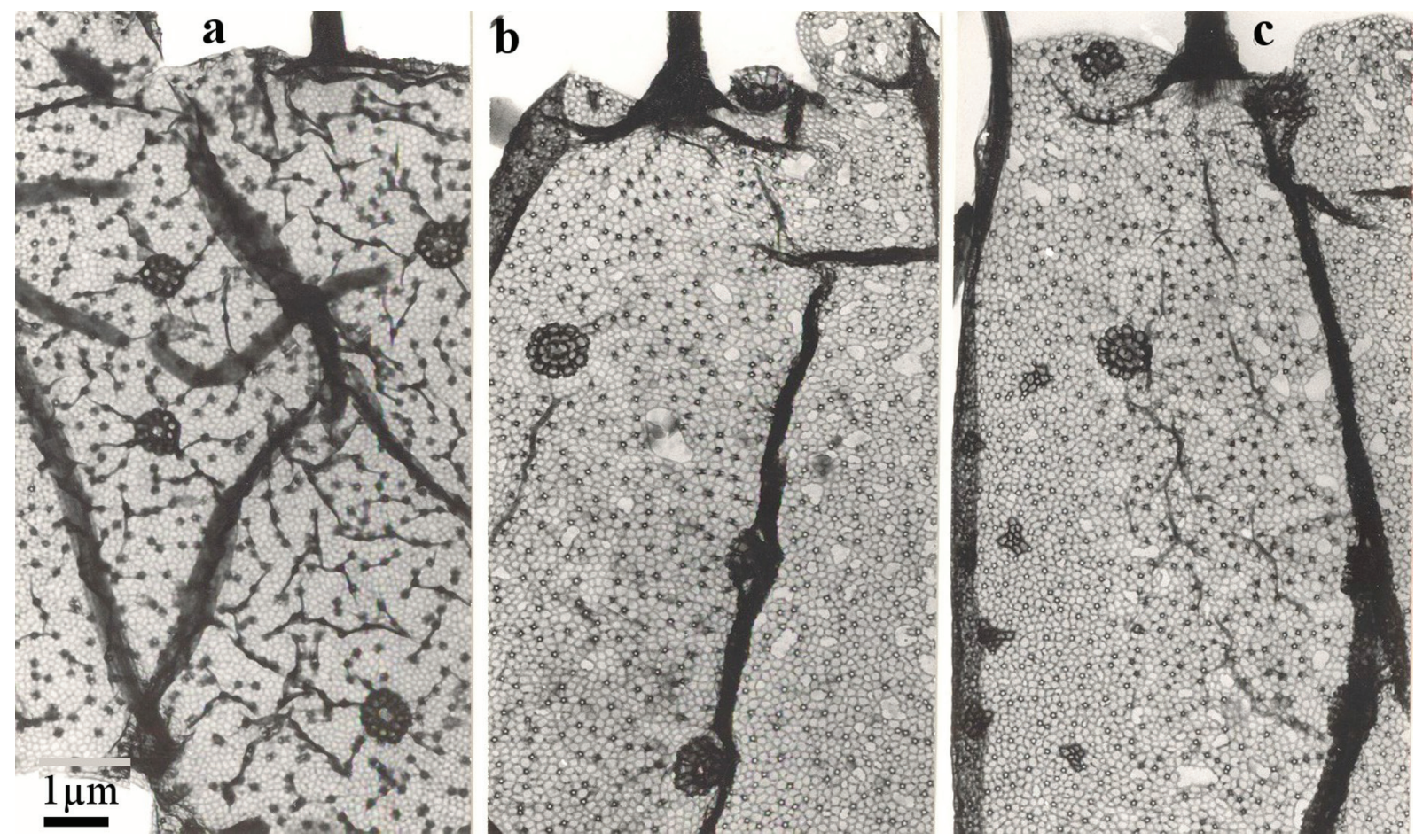

Fig. 9. Desmodesmus pseudocommunis, empty cell walls under the EM: (a) strain Hegewald 1976-43; (b, c) f. verrucosus strain Hegewald 1976-230, in (c) granules visible.

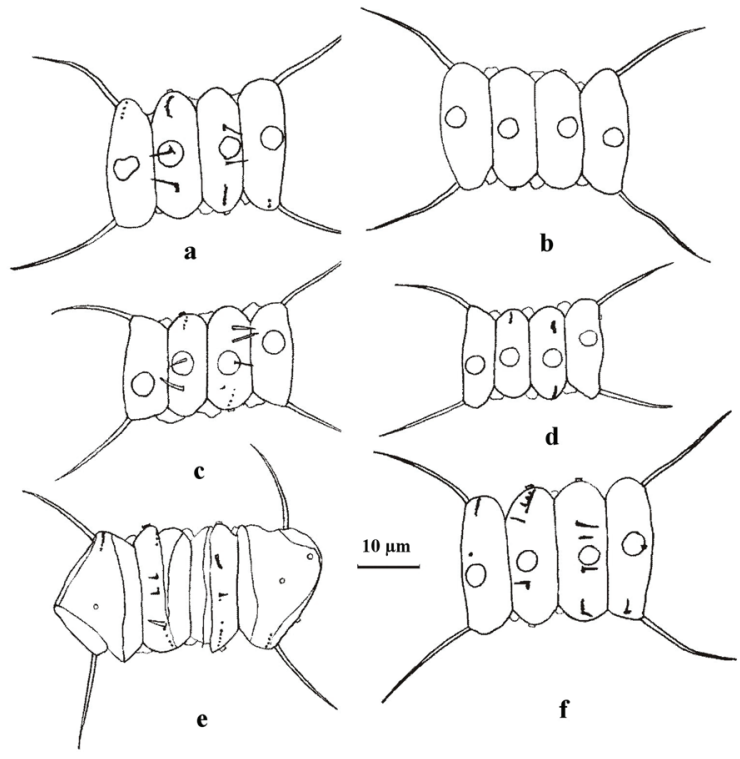

Fig. 10. Desmodesmus pseudocommunis var. texanus: (a-f) variability under the light microscope (strain Hegewald 1986-24); (e) empty cell wall.

Type strain: Hegewald 1971-257 (=CCAP 258/79). Paratype strains: Hegewald 1981-14 (Indonesia). Chic 10/23P-17w (USA).

Type locality: Lake Belső-tó, Tihany, Hungary.

Habitat: Plankton of a lake and reservoir.

Etymology: The taxon was named in honor of the late Hungarian phycologist ANTAL SCHMIDT, a good friend and coauthor for several papers.
Desmodesmus protuberans var. communioides E. Hegewald var. nov. (Figs 8c, d)

Description: coenobia quadricaudate. Cells of type strain 11.4-15.6 × 4.1-5.8 $\mu \mathrm{m}$ (average13.7 $\times 4.8$ $\mu \mathrm{m})$. Cell wall structures, rosettes and tube-like spacers were similar to those of $D$. communis. GenBank KU359302 (ITS2).

Holotype: Fig. 8d.

Type strain: Hegewald 1997-2 (=CCAP 258/132).

Syntype strains: CCALA 464 (as "Desmodesmus quadricauda"), UTEX 76 (= SAG 276-3b), EH 50, EH 52, EH 84, ET 85, ET93 (collection Vanormelingen, Belgium).

Type locality: Fiji, pond in Art Center in Pacific Harbour (island Vitu Levu)

Habitat: Plankton of a highly eutrophicated pond.

Etymology: Name was given because of a morphological similarity with Desmodesmus communis.

\section{Morphology}

The Desmodesmus communis strains had a very wide range of cell length, ITS2-sequenced strains: 9.0$23.1 \mu \mathrm{m}$ and with averages between $10.3-19.3 \mu \mathrm{m}$ (8 strains), that means, the averages of larger strains were nearly twice as large as the smaller strains. The $D$. communis var. polisicus strain was clearly larger with sizes between $21.8-34.2 \mu \mathrm{m}$. The D. pseudoprotuberans (6 strains), D. rectangularis (2 strains), D. pseudocommunis (2 strains), were within the range of $D$. communis. In average slightly larger was the strain of 

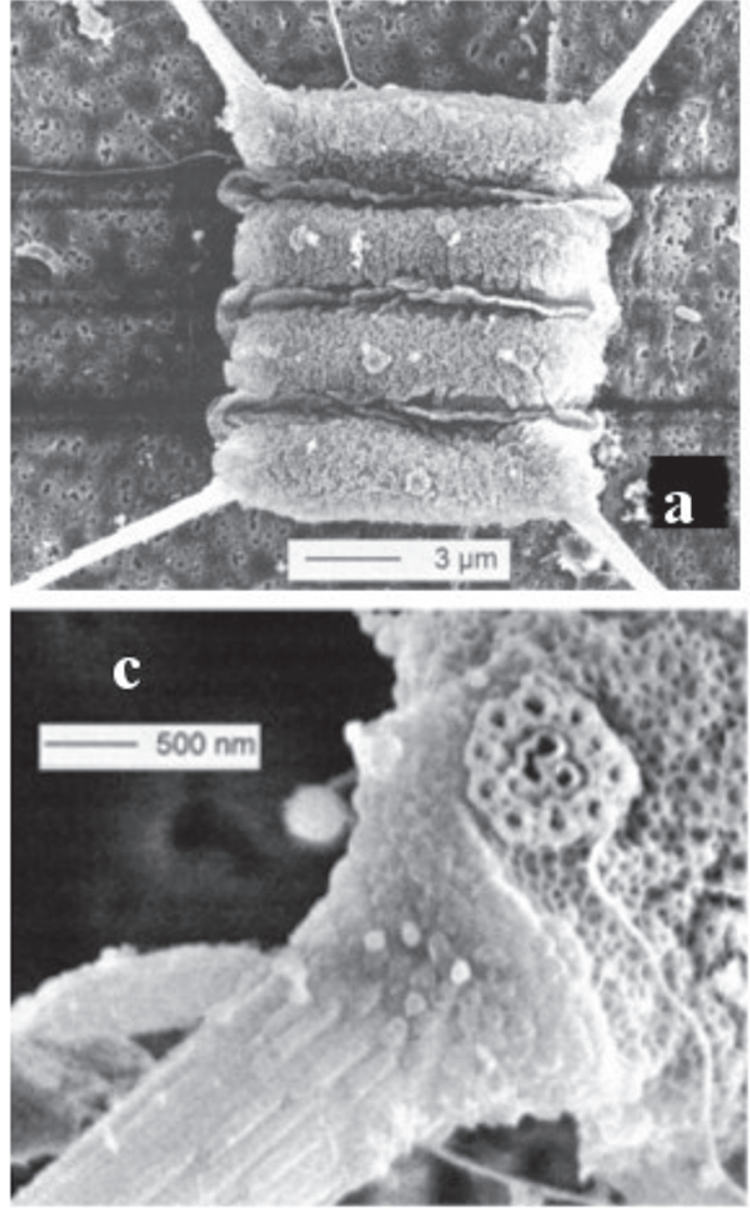

Fig. 11. Desmodesmus pseudocommunis var. texanus: (a) 4-celled coenobium with spines on the cell surface, outermost cell wall layer clearly visible between cells; (b) 4-celled coenobium with spines on the cell surface; (c) rosette and spine base; (d) short spines of different lengths, arranged in a row and with single spine beside the rosette; (e) scattered short spines of different lengths.

D. pseudocommunis f. verrucosus and the two strains of D. curvatocornis. The D. protuberans (12 strain) was mostly larger in cell size (inner cells of coenobium measured, the outer cells are larger): (11.0)15.0-31.7 $\mu \mathrm{m}$ and averages of sequenced strains between 20.3 $27.1 \mu \mathrm{m}$, but the strains of $D$. protuberans var. communioides were smaller: averages 13.2-16.7 $\mu \mathrm{m}$, smallest measured cell size $11.0 \mu \mathrm{m}$.

The cell shape was characterized by the ratio of cell length to cell width. The $D$. communis had a wide range (2.8-3.6:1), within this range were also all other studied taxa except $D$. protuberans var. protuberans (3.1-4.4:1). Hence this species had more elongated cells than the other taxa of the section (Figs 1,8). This taxon was also characterized by the outer cells of the coenobia, which were longer than the inner cells. Size differences in cell length between inner and outer cells are also found in D. pseudoprotuberans (Fig. 14), however, these are usually much less pronounced.

The spines in most taxa in the serie Desmodesmus were about cell length or shorter, in D. curvato-
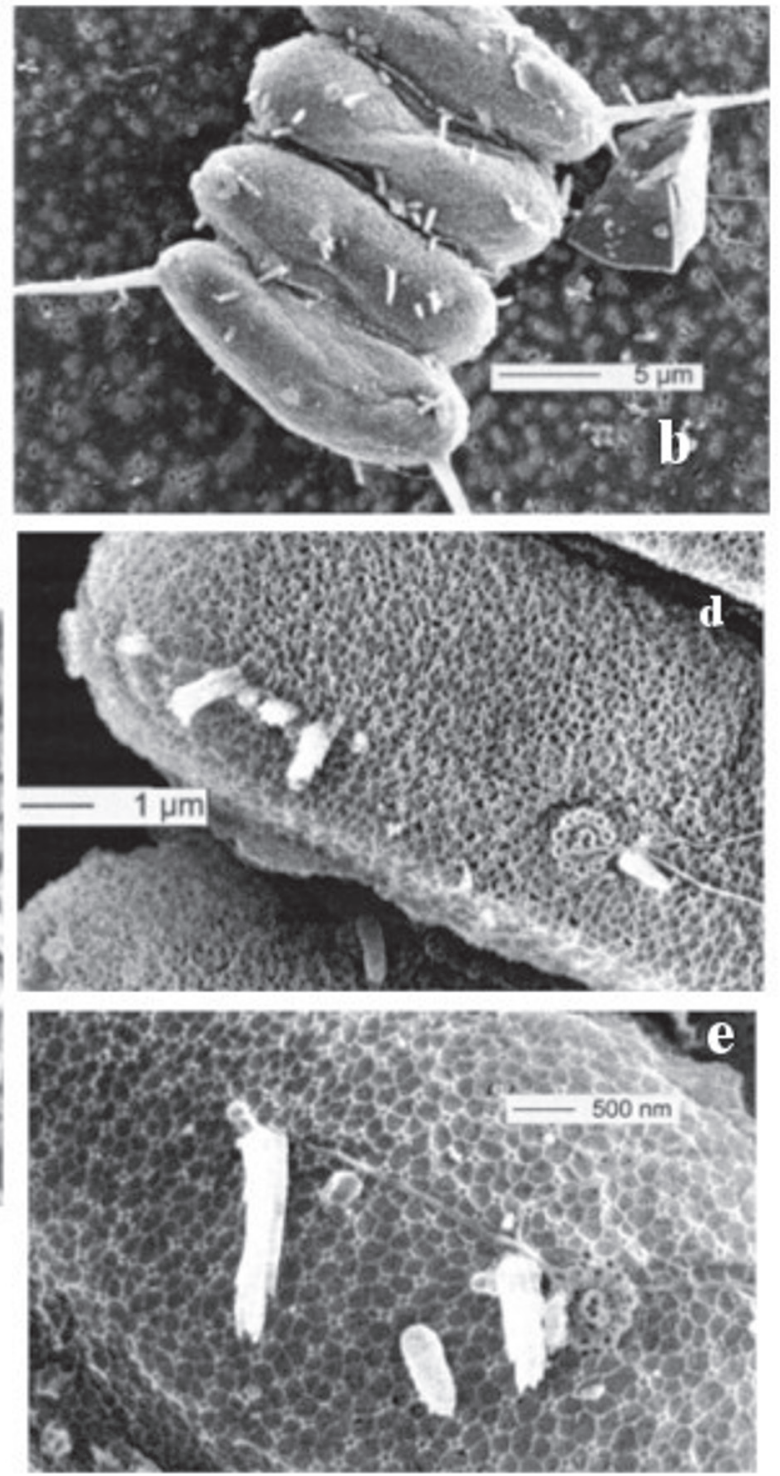

cornis, which had spines shorter than the cell diameter (Tabs 1, S2). Beside quadricaudate specimens, spineless, bicaudate and heterocaudate specimens were found in D. schmidtii, strain Hegewald 1971-257 (Fig. 19). While most of the studied taxa had a quadricaudate spination, the $D$. rectangularis had additionally short spines on one pole of the outer cells or more often short spines on one or several inner cells of the coenobia (Figs 6-7) and D. curvatocornis had sporadically an additional short spine on one pole of the outer cells (Figs 4c, 5b). The D. pseudocommunis var. texanus sporadically had spines scattered over the cells, sometimes connected with fragmented ribs, which are found in all taxa of the subsection only in this variety (Figs $10,11)$. Spines are always bundle of tubes, but in var. texanus we observed a warty structure at the base of the spines (Fig. 11c).

Single tubes were observed on the cells of $D$. curvatoronis (Figs 5e-f). 


\section{Cell wall ultrastructure}

We discussed following structures: nets, rosettes, and tube-like spacers.

Net-like structures: All studied taxa had an outer cell wall layer, carried by spacer tubes (Figs 3a, 11a, 15c). The outer cell wall layer had a reticulate net-like structure built of filaments attached on the outermost cell wall layer (Figs 5d, 9, 17d). This reticulate structures were different in different taxa. The $D$. communis and var. polisicus, $D$. pseudoprotuberans, D. schmidtii and $D$. protuberans and its variety had a structure with very irregular meshes (e.g. Fig. 17d), while D. pseudocommunis and $D$. curvatocornis had a very regular net-like structure with smaller mashes and stronger filaments (e.g. Fig. 5d). For two strains of different taxa the net-like structures were measured. The structure was characterized by mesh area or largest diameter of the meshes. In Fig. 20 is shown the mesh area distribution for these two taxa. The D. pseudocommunis f. verrucosus (strain Hegewald 1975-230) had a small mash area and regular net-like structure, hence it had a sharp distribution peak for the mesh area, while $D$. communis (strain Hegewald 1974-8) had an irregular net of very different mesh-sizes, hence a flat and wide distribution curve. For the screening of many strains we measured the smallest and largest mesh diameter only (Table S2).

\section{Rosettes}

The rosettes were special structures: openings in the outer cell wall layer for excretion of bristles (Fig. 16), which were produced from basal props (Figs 13a, f). We distinguished four types of rosettes:

- type Ia composed of 4 or 5 (rarely 6) tubes, which lose their central walls at the bottom (Figs 3a, b). Often one or several space holder tubes were attached (Fig. 3d, Table S2). These types of rosette were found in strains of $D$. communis with smaller cell sizes and in D. protuberans (Table S2).

- type Ib was similar to type Ia, but had additionally a central short tube. These types of rosette were found in strains of $D$. communis with larger cell sizes (Fig. 1). Often were found reduced or abnormal rosettes. In a few strains no rosettes were found.

- type IIa was more complex and had a larger number of outer (9-14) and central tubes (2-4). The central tubes had a reduced central wall, hence forming one central opening (13d, h). In the upper part of the rosette the outer tubes were connected to the central tubes by rods (Fig. 13h). This type is found in D. pseudocommunis.

- type IIb differs by connections of the outer tubes which were ladder-like (Fig. 15d). This type is found in D. pseudoprotuberans.

Tube-like spacers: Between the three inner cell wall layers and the outer layer were tube-like spacers.
These tubes were in cross section 4- or 5-cornered, exceptionally 3-cornered or round. The $D$. communis has 4-corned tubes (rarely 5- or 3-cornered) as do also $D$. protuberans and $D$. pseudoprotuberans. The $D$. pseudocommunis has mainly 5 -cornered and less common 4-cornered tubes. The section Maximi had circular tubes while $D$. intermedius (R.CHOD.) E.HEGEwALD (subgenus Desmodesmus Section Intermedius) had three-cornered tubes only.

\section{ITS-2}

The eleven sequenced strains of $D$. communis as additional data from GenBank (Table S1) were identical in ITS-2 base composition, but the strains Hegewald 1977-170 and AICB 989 differed in one base. The strain Hegewald 1977-170 had also four differences in the last 52 bases of $5.8 \mathrm{~S}$ DNA. All five differences were $\mathrm{G}$ instead of $\mathrm{C}$ or $\mathrm{U}$. The two strains of $D$. curvatocornis and the strain of D. communis var. polisicus were identical in ITS-2 with the $D$. communis strains (Fig. 21). Two strains of D. schmidtii (Hegewald 1971-257, Hegewald 1981-14) were morphologically similar with $D$. communis but the outer cells could be a little bit larger than the inner ones. However, in ITS-2 (strain Hegewald 1981-14, Fig. S5) they fit into the $D$. protuberans-group (Fig. 21). The D. schmidtii strains differ from $D$. protuberans by 3-5 bases and from $D$. communis by 6 bases (Table S3). The D. protuberans differed from $D$. communis by $5-7$ bases (Table S3). The D. protuberans-group (D. protuberans/D. protuberans var. communioides, $/ D$. pseudoprotuberans $/ D$. schmidtii) is characterized by several base exchanges in the top of helix II, especially by an exchange in position 81 ( $\mathrm{G}$ or $\mathrm{U}$ ) and an additional $\mathrm{U}$ between position 83 and 84 . These changes result in a prolongation of helix II by one base pair.

The $D$. rectangularis differs from $D$. communis by 2 bases only (Fig. S1, Table S3), the D. pseudocommunis by $5-6$ (Fig. S3, Table S3) and the D. pseudoprotuberans by 8-9 (Table S3, Fig. S4). The members of the related serie Maximi differ by 25-29 bases from D. communis. All taxa of the serie Desmodesmus had no $\mathrm{CBC}$ (compensatory base change) between each other but they had 1-5 CBC's compared to serie Maximi (Table 2).

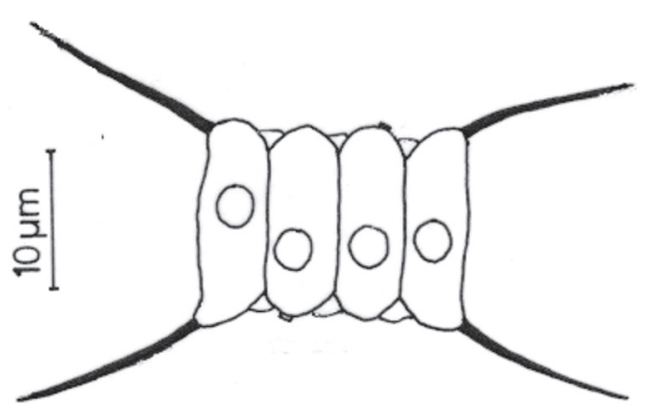

Fig. 12. Desmodesmus pseudocommunis f. verrucosus, strain Hegewald 1975-230, habitus. Scale 10um. 


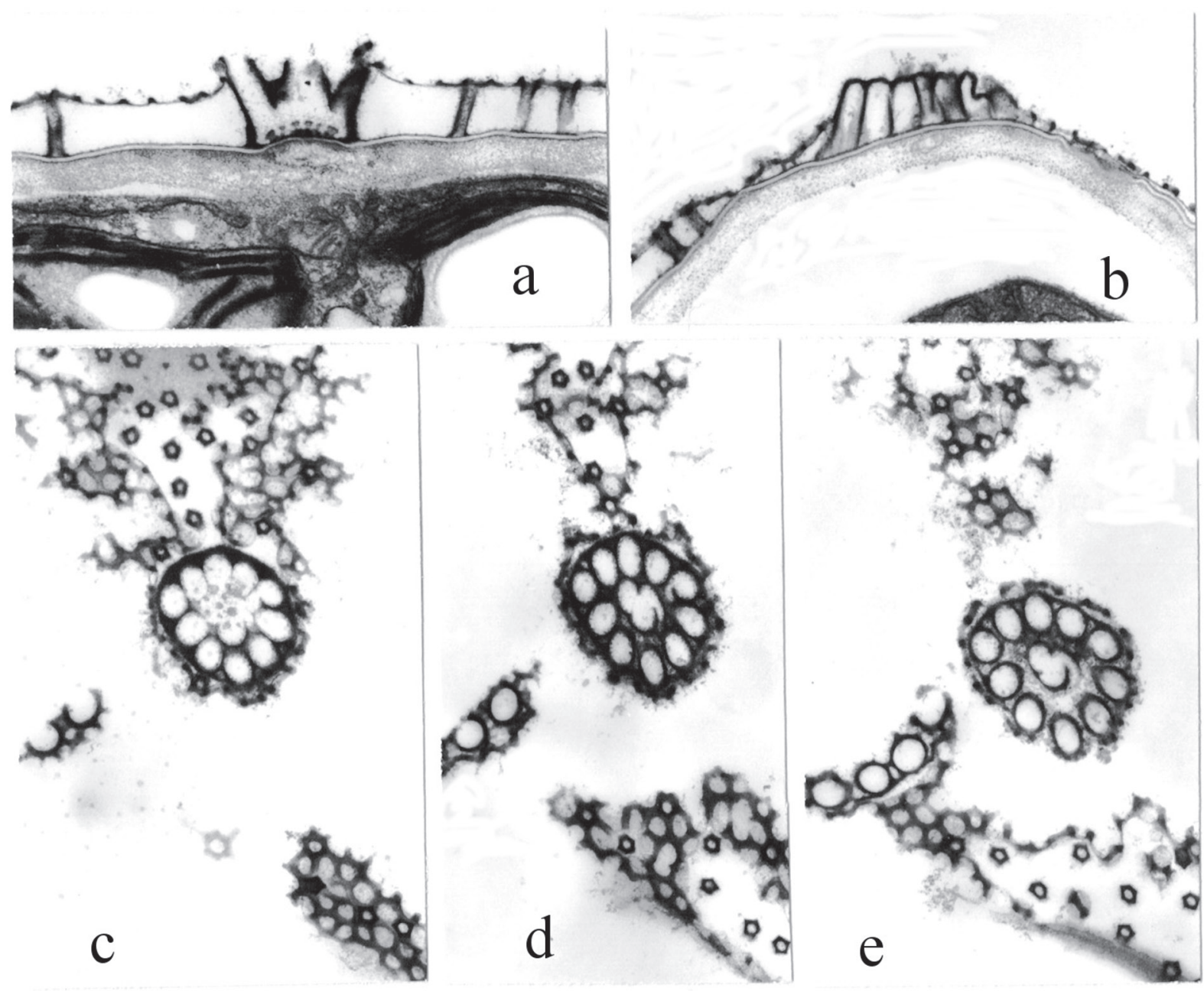

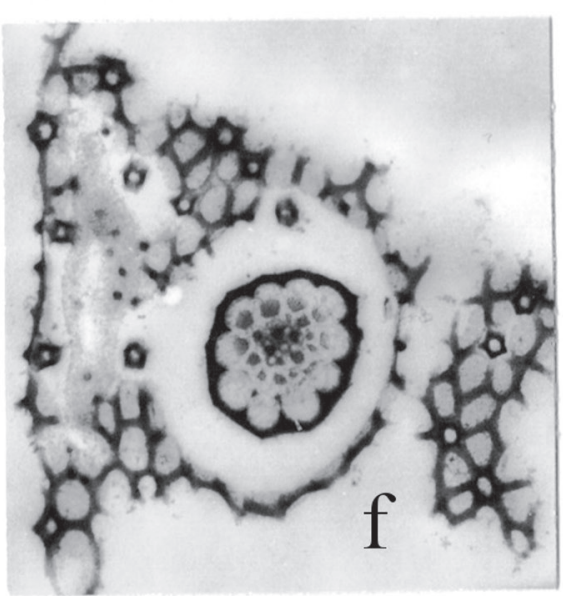

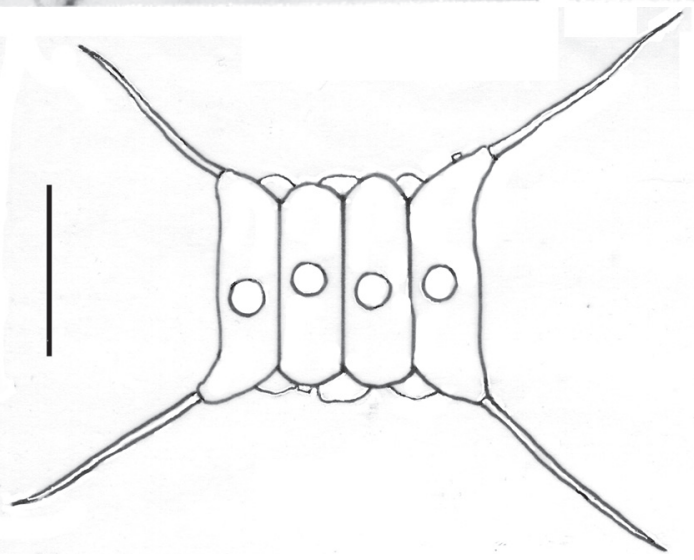

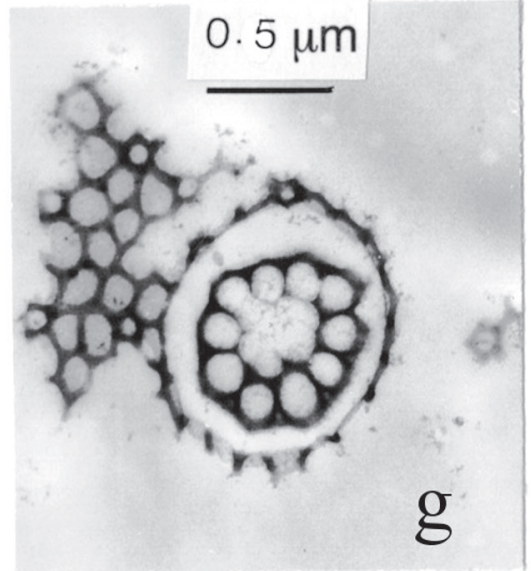

Fig. 13. Desmodesmus pseudocommunis f. verrucosus, strain Hegewald 1975-230: (a) longitudinal section through a rosette; (b) group of tubes, building the granules; (c-e) and (f-h) two series of serial cross-sections of rosettes from bottom to top.

Fig. 14. Desmodesmus pseudoprotuberans, type strain: Hegewald 1973-293 (Peru, Rio Nanay). Scale $10 \mu \mathrm{m}$. 

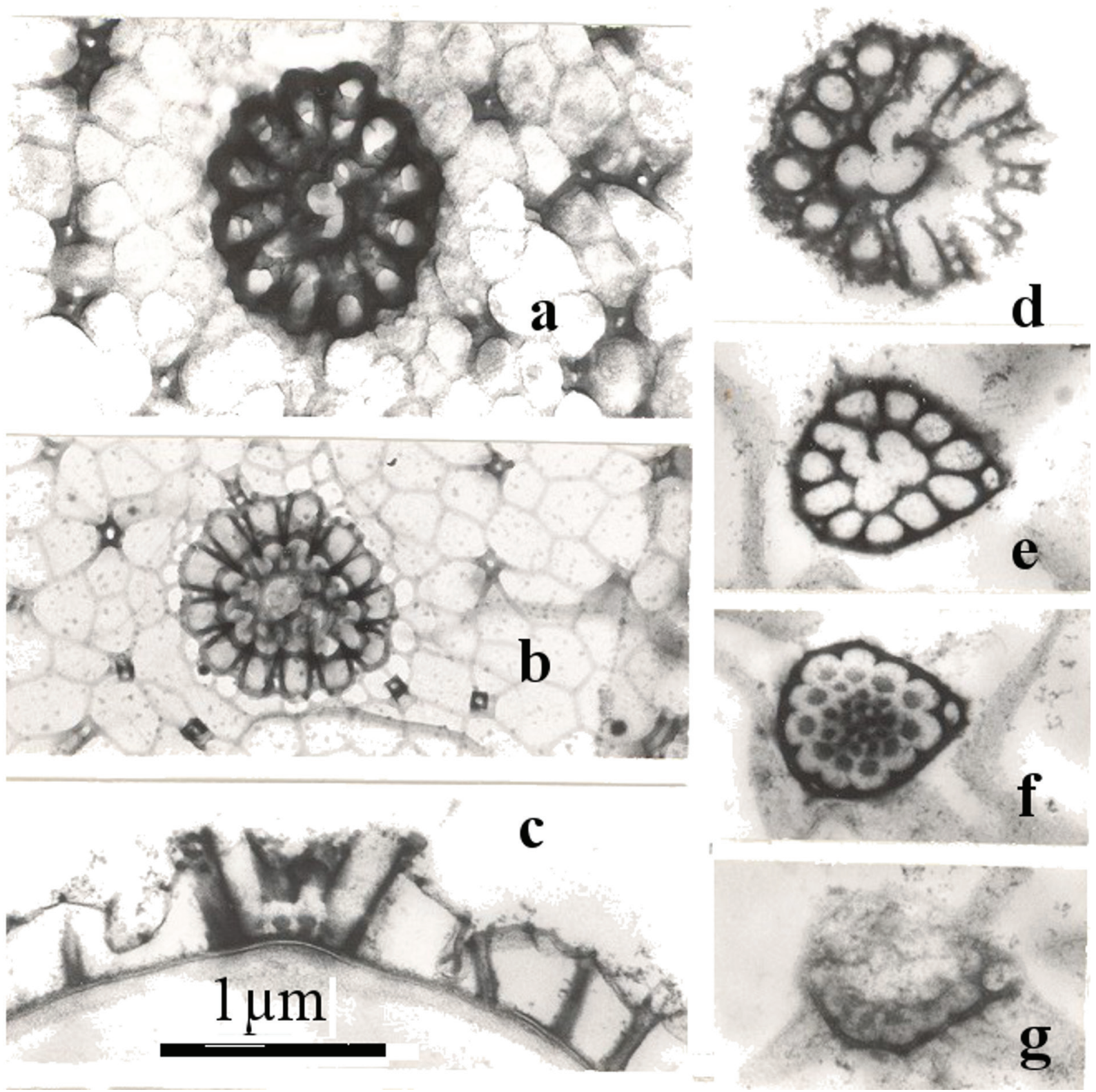

Fig. 15. Desmodesmus pseudoprotuberans strain Hegewald 1973-293 under the EM: (a, b) top view on rosettes; (c) longitudinal section of a rosette; (d-g) serial sections through a rosette from top to bottom.
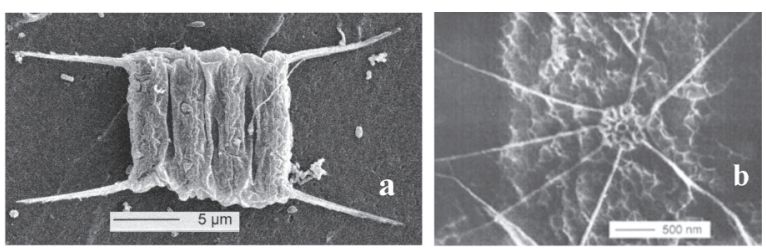

Fig. 16. Desmodesmus pseudoprotuberans strain Hegewald 1981-51 under the EM: (a) habitus; (b) rosette with excreted bristles.

For all studied taxa most base exchanges were in helix I and II: 21, in helix III there were two and in helix IV there were three (Fig. S6).

For the serie Desmodesmus most of the base exchanges were in loops. If we count the changes in helices only, the D. communis is distinguished from
$D$. rectangularis and from $D$. pseudocommunis by one base only, from $D$. protuberans by two and from $D$. pseudoprotuberans and D. schmidtii by three.

\section{Discussion}

The recent unforced conservation of the species name Achnanthes (Scenedesmus) quadricauda TuRPIN in the ICBN (Greuter 2000) should be followed. However, we do not recommend doing it, because this conservation has to be reconsidered. Beside the fact, that $A$. quadricauda is related to the Desmodesmus armatusgroup, but different from Desmodesmus communis (Hegewald 1977), it makes no sense, to retain a name 

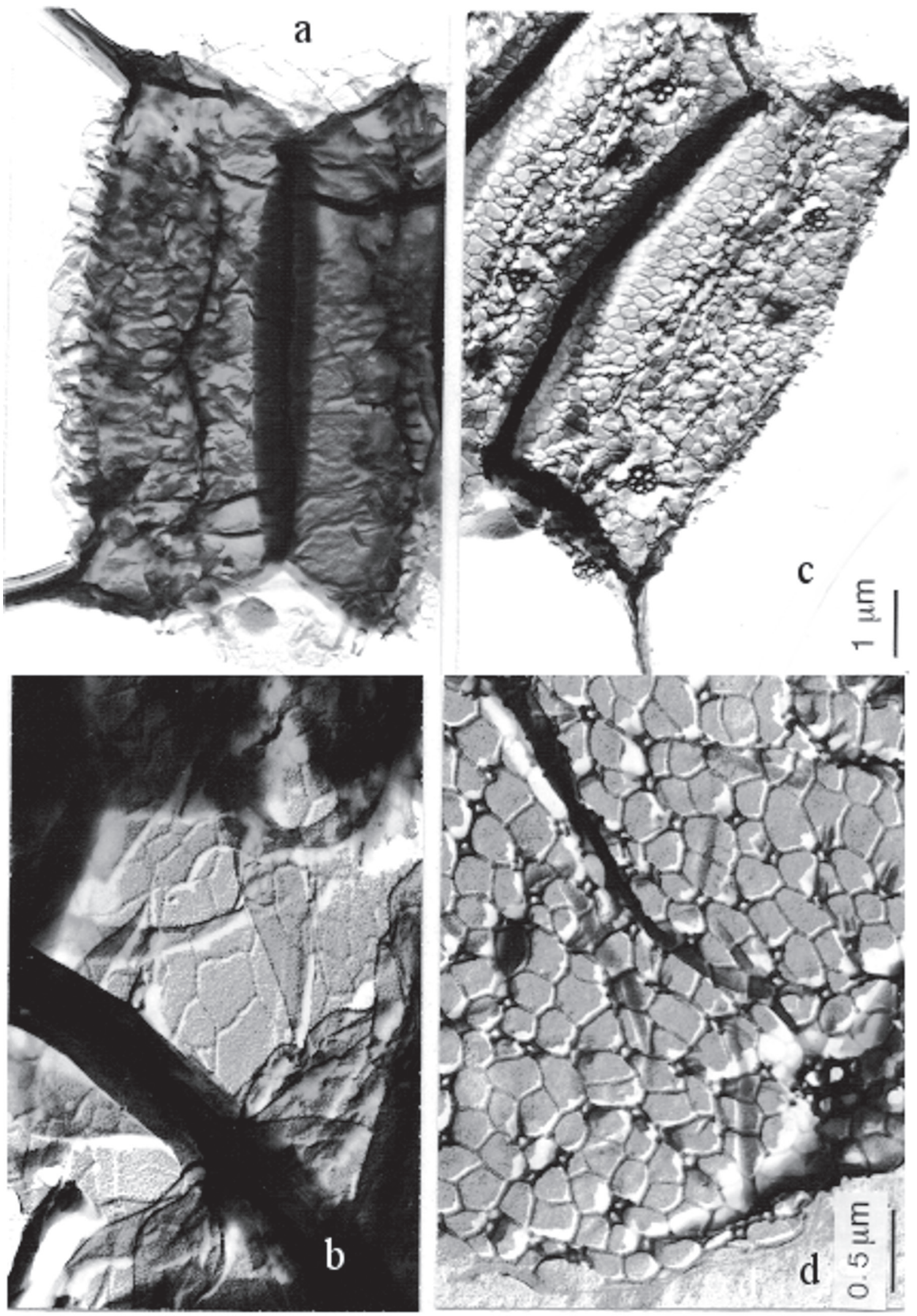

Fig. 17. Desmodesmus schmidtii, strain Hegewald 1971-257: (a) cell wall ultrastructure; (b) detail; Desmodesmus communis strain Bai 197126; (c) cell wall ultrastructure; (d) detail. Both strains are isolated from the same pond (Belsö-tó, Hungary). Scale in b also for a, scale in d also for $\mathrm{c}$. 


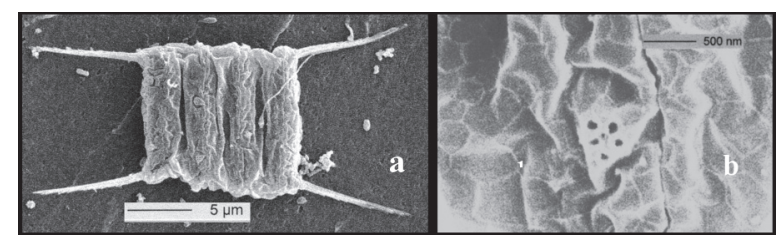

Fig. 18. Desmodesmus schmidtii, strain Hegewald 1981-14: (a) habitus; (b) rosette and delicate cell wall structures under the SEM.

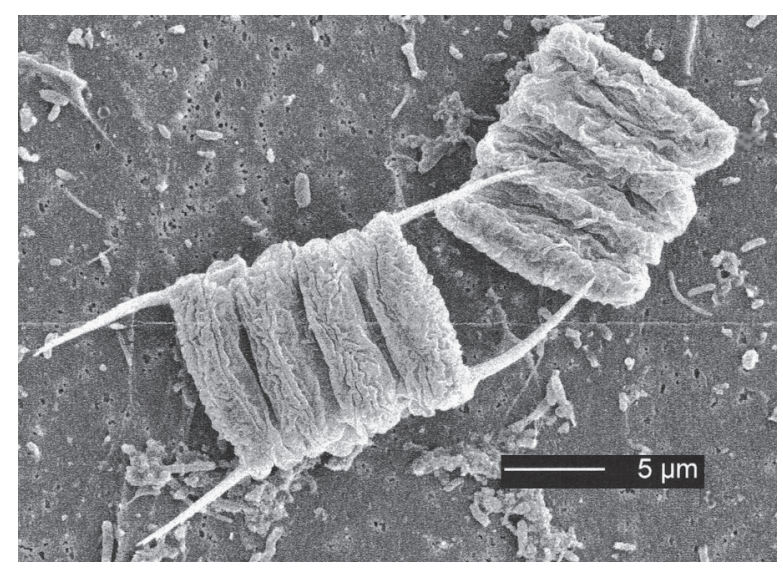

Fig. 19. Desmodesmus schmidtii, strain Hegewald 1971-257: a spiny and a spineless coenobium under SEM.

with author name, but exclude its type and use instead as type a strain of a different taxon "[specimen from strain] Hungary, Lake Belsö-tó, Hegewald 1971/ 256 (Research Center Jülich, Germany) (typ. cons.)". This strain was already the type of Scenedesmus communis Hegewald (1977) and it cannot be used for two different taxa. The strain was lost years ago. However, fixed samples of the strain were distributed to different herbaria. This strain was isolated in 1971, hence about 150 years after the description of Achnanthes quadricauda.

The first illustration of the A. quadricauda was about 1820 by TuRPIN (1816-1829). This taxon is similar to $D$. armatus var. longispina (CHODAT) E. HeGEWALD et HINDÁK, while A. quadricauda of TURPIN (1828) resembles D. opoliensis (P. Richt.) E.Hegewald as discussed by CHOdat $(1913,1926)$, see also Hegewald (1977). In order not to not fall back to the confusion of the past, we recommend using the name Desmodesmus communis (E.Hegewald) E.Hegewald for a well-defined taxon instead of using of the name "Achnanthes/ Scenedesmus quadricauda". Sporadically in literature the combination "Desmodesmus quadricauda (TURPIN) E.HEGEWALD" was also found, but it is an invalid combination. E. HEGEWALD never used such a combination and would not do so.

A synopsis for the group studied here is given in Fig. 1. The D. communis was well described by HEGEWALD (1977). However, our studies here, based on EM and DNA, showed the existence of several closely related taxa. The $D$. communis is in nature a common taxa (Table S1). Under light microscope, under elec-

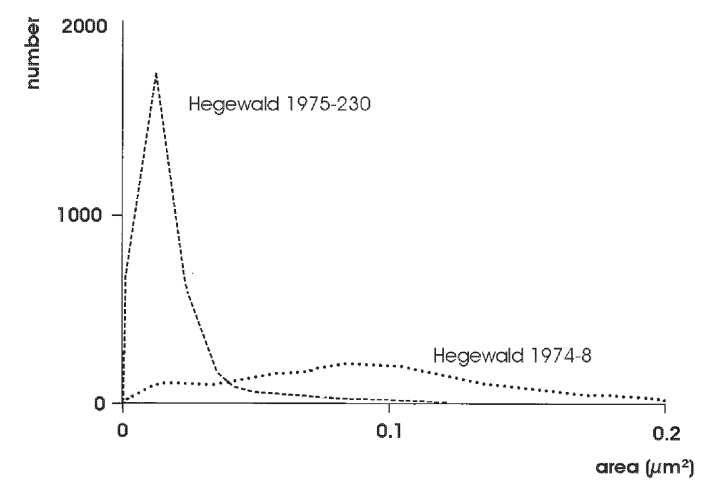

Fig. 20. Distribution of mesh sizes of two strains, Hegewald 1974-8 Desmodesmus communis and Hegewald 1975-230 Desmodesmus pseudocommunis f. verrucosus.

tron microscope and/or according to ITS-2 base sequence it was distinguishable from other taxa of the group. Desmodesmus communis had a wide range in cell size and all other taxa studied here were within this cell size range, except the $D$. protuberans which had the outer cells longer than inner of the coenobia (for our comparison only inner cells of the coenobia were measured) and additionally it had more elongated cells than $D$. communis. For $D$. protuberans a forma minor was also described by LeY (1947). Its cell size range was $22-25 \mu \mathrm{m}$, hence in the range of $D$. protuberans. The D. protuberans var. communioides differed from D. protuberans var. protuberans in two bases only, but it is somewhat smaller in cell size and the outer cells of the coenobia were not or only slightly longer than the inner cells. Morphologically it was hardly or not at all possible to distinguish the taxon from $D$. communis. In ITS2 it differed from $D$. communis and was clearly close to D. protuberans (Fig. S1), hence we treated it as a variety of $D$. protuberans and not of $D$. communis. The first author, although he studied the genus for decades, had determined the strain UTEX 76 as D. communis (Hegewald 1989). The strain UTEX 76 is identical with strain SAG276/4b (HegewaLd 1982), hence both strains were not $D$. communis but $D$. protuberans var. communioides. The taxa $D$. communis and $D$. protuberans var. communioides needed ITS2 determination for reliable identification. Because the first author has been retired for several years, we had no chance to culture, measure and sequence all doubtful strains. Hence the taxonomy of $D$. protuberans and $D$. communis could not yet be finally resolved. The strains of D. communis were identical in ITS2 (exept strain Hegewald 1977-170, isolated from Lake Titicaca, Peru) while $D$. protuberans and its variety had several strains with base exchanges (Fig. 17), e.g. UTEX 76 (GenBank AM410660) and SAG 276/4b (unpublished data of KitschKe) had one base exchange (position 221), and strains EH 52, EH 84, ET 85 of VANORMELINGEN in position 24 .

The cell size depended on temperature (KoMÁREK \& RuŽIČKA 1969) and other culture condi- 
tions as was shown in Table 4. Medias having low salt concentration produced smaller cells. Therefore in medium CHU X the smallest cells were always produced, in the medium of Pringsheim with additional $\mathrm{CO}_{2}$ the largest coenobia were produced. Intermediate were cultures with medium Pringsheim, but without additional $\mathrm{CO}_{2}$. Hence for the group (serie Desmodesmus) studied herein, the cell size is not always useful for distinguishing the studied taxa.

Desmodesmus curvatocornis was not a true planktonic species, in culture the strain Hegewald 1977-144 was "foaming in pack" and sedimentated easily. Although it is not different from $D$. communis in ITS2 it is morphologically strikingly different from that species and a relationship between these species was never suspected. However, it was overlooked that the outer cell wall layer was visible between the cell poles even under the light microscope, which clearly indicates its relationship to $D$. communis. The spines of the taxon are short and often strongly curved. Extraordinary for the subsection are the single tubes scattered on the surface (Figs 5c, e). Eventually these are responsible for the above mentioned cell packs.

The $D$. rectangularis differed under the light microscope from D. communis var. communis in cell shape and spine length. The cell tips were not acute as in the typical variety but were obtuse to truncate. Additionally short spines were often produced in a polar region on one of the cell poles of the outer cells and of the neighboring cell of the coenobia (e.g. ACOI 1438 sub nom. „Scenedesmus smithii Chodat“, see http:// acoi.ci.uc.pt/spec_detail.php?searchSpecie2=ACOI1438\&cult_id=1498 and Fig. 6). The Scenedesmus smithii CHODAT had some morphological similarity, but the taxon had a much smaller cell size than $D$. rectangularis and it seems to be another taxon. All seven strains of $D$. rectangularis had only two differences in ITS2 compared to D. communis: a semi-CBC in helix I and one exchange in the end loop of helix III (Fig. 16).

The five strains of $D$. pseudocommunis and its variety and forma, had compared to D. communis one semi-CBC and 5 exchanges in loops (Fig. 18).

The five sequenced strains of $D$. pseudoprotuberans (including its variety and its forma) had eight differences to D. communis: four in loops, one additional base in a loop and three semi-CBC's (Fig. 19). The morphology of species resemble $D$. protuberans by longer outer than inner cells but it is smaller in size.

In Fig. 21 the development of the different taxa was shown. Most taxa apparently were developed in one step only, but in the D. pseudocommunis-branch the subtaxa f. verrucosus and var. texanus (not mentioned in Fig. 21 because not ITS2 data were available) were included. These taxa differ not in ITS2 (as far as analyzed), but in cell wall ultrastucture only. However, the "D. protuberans branch" is subdivided and included D. protuberans and its var. communioides, D. pseudoprotuberans and D. schmidtii. All these taxa were similar in cell wall ultrastructure to $D$. communis (although reduced structures in D. schmidtii) but differed in ITS2.

Although the differences of the taxa in ITS2 are low in number, these differences were consistent in all strains of the taxa. We put our main weight on the ITS2 data and on the cell wall ultrastructure.

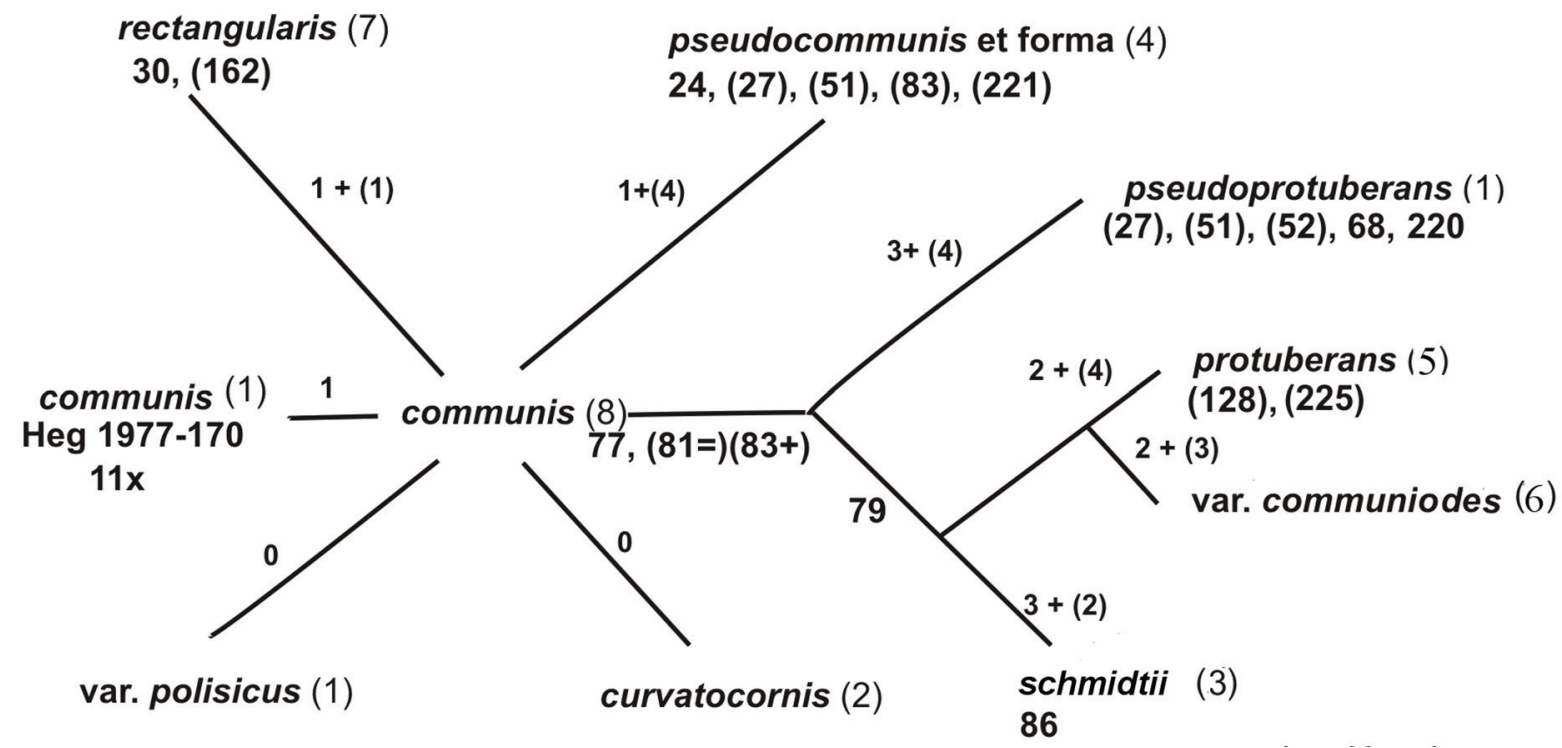

Fig. 21. Differences between D. communis and related taxa according to ITS-2 base composition. Number in brackets after taxon name: number of sequenced strains; number below taxon name: position of bases exchanged (see Figs 17-20). Number without brackets: exchange in helix; with brackets: exchange in loop; number followed by "=": base exchange resulted in a new base pair; number followed by "x": base exchange resulted in breaking of base pair; 83+: additional base after position 83; number above final branches: number of base exchanges; number below branches: base position exchanged in all taxa of the following cluster. 
Table 3. Cell size of cultures in different media or methods: (a) medium Pringsheim, bubbled with $1 \% \mathrm{CO}_{2}$; (b) Medium Pringsheim, shaken cultures; (c) medium CHU X, shaken cultures; (L) length; (W) width.

\begin{tabular}{cccc}
\hline culture & $\mathbf{L} \times \mathbf{W}$ & $\mathbf{L} / \mathbf{W}$ & $\mathbf{L} \times \mathbf{W}$ \\
method & average & & $\min -\mathbf{m a x}$ \\
\hline
\end{tabular}

\begin{tabular}{llrrr}
\hline Desmodesmus communis & & & & \\
Bai 1971-26 & a & $12.0 \times 4.3$ & 2.9 & $10.8-13.2 \times 3.6-5.4$ \\
& b & $10.3 \times 3.4$ & 3.1 & $9.0-11.4 \times 3.0-4.2$ \\
& c & $9.5 \times 3.2$ & 3.0 & $8.4-11.4 \times 2.7-3.9$ \\
Hegewald 1971-256 & a & $11.6 \times 4.4$ & 2.7 & $10.2-13.8 \times 3.3-5.4$ \\
& b & $10.4 \times 3.7$ & 2.9 & $9.0-13.2 \times 2.5-5.4$ \\
Hegewald 1973-66 & c & $9.3 \times 3.1$ & 3.0 & $8.4-9.6 \times 3.0-3.3$ \\
& a & $14.7 \times 5.2$ & 2.8 & $12.0-18.6 \times 3.9-6.6$ \\
& b & $14.2 \times 4.0$ & 3.6 & $12.6-18.0 \times 3.0-6.3$ \\
& c & $12.4 \times 4.7$ & 2.6 & $10.8-13.8 \times 3.9-5.4$
\end{tabular}

Desmodesmus pseudoprotuberans E.HegewaLd

\begin{tabular}{lcccc} 
Hegewald 1973-293 & a & $16.4 \times 6.0$ & 2.8 & $15.0-18.6 \times 4.8-7.2$ \\
& b & $17.5 \times 5.0$ & 3.5 & $15.0-19.2 \times 4.2-6.6$ \\
Hegewald 1973-295 & c & $16.0 \times 5.3$ & 3.0 & $12.0-18.0 \times 3.9-6.0$ \\
& a & $16.9 \times 6.8$ & 2.5 & $15.0-18.0 \times 4.8-7.8$ \\
& b & $18.3 \times 5.6$ & 3.4 & $15.0-22.8 \times 3.6-7.8$ \\
Hegewald 1973-303 & c & $14.0 \times 4.7$ & 3.0 & $12.0-18.6 \times 3.6-6.6$ \\
& a & $17.2 \times 6.9$ & 2.5 & $14.4-18.6 \times 6.0-7.8$ \\
& b & $17.8 \times 5.9$ & 3.1 & $15.0-21.0 \times 5.4-6.6$ \\
Desmodesmus protuberans & c & $14.5 \times 5.0$ & 2.3 & $12.6-16.8 \times 4.2-6.0$ \\
Hegewald 1971-23 & a & $20.9 \times 5.3$ & 3.9 & $18.0-25.2 \times 4.2-6.6$ \\
& b & $21.8 \times 5.2$ & 4.3 & $18.0-24.0 \times 3.6-6.3$ \\
& c & $20.3 \times 5.5$ & 3.7 & $18.0-24.0 \times 4.5-6.0$ \\
\hline
\end{tabular}

\section{SUMMARY}

The serie Desmodesmus ("D. communis group") includes several taxa and some of these were difficult to distinguish. Desmodesmus communis had a wide range of characteristics and for its differentiation to $D$. communis var. polisicus and D curvatocornis morphological and cell wall ultrastructural characteristics were necessary. Although D. protuberans var. protuberans was morphologically clearly distinct, its var. communioides was similar to D. communis and ITS2 data were necessary for distinguishing these taxa. Cell wall ultrastructures or ITS2 alignment based on secondary structure information served for the identification of $D$. pseudocommunis, D. smithii, D. rectangularis and $D$ pseudoprotuberans.
While the for D. communis as typically suspected, quadricaudate spination were found in D. communis, its var. polisicus and in D. protuberans, D. pseudocommunis and D pseudoprotuberans. The D. schmidtii also produced additionally bicaudate and spineless (!) coenobia. Desmodesmus rectangularis and D. curvatocornis had often in addition short spines on outer and or inner cells, while D. pseudocommunis var. texanus sometimes had short spines scattered over the cell wall surface or arranged in short rows.

ACKNOWLedgments

We thank especially E. Schnepf and Mrs. G. DeichgräBer, Heidelberg, Germany for their skilful and extensive work at the electron microscope. R. RAmirez and D. BRown, both Austin, Texas, USA for help with the TEM. For EM studies done in Juelich, we thank 
H.-P. Bochem and for numerous photo prints S. PETERS (both Juelich, Germany). P. vanormelingen (Gent, Belgium) and M. Fawley (Monticello, Arkansas, USA) we thank for ITS2 data. We thank Mrs. V. Schäfer, G. Groehn and P. Hegewald (all Juelich, Germany) for culturing the isolates and Company Zeiss, (Cologne, Germany) for the loan of a Videoplan used for size measuring of the electron microscopical structures. For her help with measuring the EM structures we thank especially Mrs R. Paschma-Koch (Wallitz, Germany) and also Mrs I. Hosdorf (Neuerburg, Germany). and L.Krienitz (Burow, Germany) we thank for samples from Kenia. C.-J. SoEder (Dortmund, Germany) we thank for support and discussions and for language correction N. StarR (Mission, Kansas, USA)

\section{REFERENCES}

An, S. S.; Friedl, T. \& Hegewald, E. (1999): Phylogenetic relationships of Scenedesmus and Scenedes-mus-like coccoid green algae as inferred from ITS-2 rDNA sequence comparisons. - Plant Biol. $1: 1-11$.

Bica, A.; Barbu-Tudoran, L.; Drugă, B.; Coman, C.; NiCOARĂ, A.; SzÖKE-NAgY, T. \& Dragoș, N. (2012): Desmodesmus communis (Chlorophyta) from Romanian freshwaters: coenobial morphology and molecular taxonomy based on the ITS2 of new isolates. - Annals of RSCB 17: 16-28.

Chodat, R. (1913): Mononographies d'algues en culture pure. - Matériaux pour la Flore Cryptogamique Suisse 4: 1-266.

Chodat, R. (1926): Scenedesmus. Etude de génétique, de systématique expérimentale et d'hydrobiologie. - Rev. Hydrol. 3: 71-258.

Compère, P. \& KomÁrek, J. (1990): (983) Proposal to conserve Scenedesmus quadricauda (TURPIN) BRÉBISSON with a conserved type under Art. 69.3 (algae). - Taxon 39: 530-531.

Corda, A. J. C. (1835): Observations sur les animalcules microscopiques, qu'on trouve auprès des eaux thermales de Carlsbad. - Almanach de Carlsbad 5: 16621

EhrenberG, C. G. (1834): Dritter Beitrag zur Erkenntnis großer Organisation in der Richtung des kleinsten Raumes. - Abhandlungen der Königlichen Akademie der Wissenschaften zu Berlin, Physikalische Klasse 1833: $145-336$.

Greuter, W.; McNeill, J.; Barrie, F. R.; Burdet, H.-M.; Demoulin, V.; Filgueiras, T. S.; Nicolson, D. H.; Silva, P. C.; Skog, J. E.; Trehane, P.; Turland, N. J. \& Hawksworth, M.D.L. (2000): International Code of Botanical Nomenclature (St Louis code).- Regnum Vegetabile 138. Koeltz Scientific Books, Königstein; http://www.bgbm.org/IAPT/Nomenclature/Code/ SaintLouis/0000St.Luistitle.htm

Hegewald, E. (1977): Scenedesmus communis Hegewald, a new species and its relation to Scenedesmus quadricauda (Turp.) BRÉB. - Arch. Hydrobiol./Suppl. 51, Algological Studies 19: 142-155.

Hegewald, E. (1979): Vergleichende Beobachtungen an Herbarmaterial und Freilandmaterial von Scenedesmus. - Arch. Hydrobiol./Suppl. 56, Algological Studies 24: 264-286.

Hegewald, E. (1978): Eine neue Unterteilung der Gattung Scenedesmus Meyen. - Nova Hedwigia 30: 343-376.

Hegewald, E. (1982): Taxonomisch-morphologische Unter- suchung von Scenedesmus-Isolaten aus Stammsammlungen. - Arch. Hydrobiol./Suppl. 60, Algological Studies 29: 375-406.

Hegewald, E. (1984): Hochtemperaturstämme in der Gattung Scenedesmus Sektion Desmodesmus. - Arch. Hydrobiol./Suppl. 67, Algological Studies 37: 441-446.

Hegewald, E. (1989): The Scenedesmus strains of the Culture Collection of the University of Texas at Austin, Texas (UTEX). - Arch. Hydrobiol./Suppl. 82, Algological Studies 55: 153-189.

Hegewald, E. (1997): Taxonomy and phylogeny of Scenedesmus. - Algae (Korean Journal of Phycology) 12: 235-246.

Hegewald, E.; Bock, C. \& Krienitz, L. (2013): A phylogenetic study on Scenedesmaceae with the description of a new species of Pectinodesmus and the new genera Verrucodesmus and Chodatodesmus (Chlorophyta, Chlorophyceae). - Fottea: 149-164.

Hegewald, E.; Coesel, P.F.M. \& Hegewald, P. (2001): A phytoplankton collection from Bali, with the description of a new Desmodesmus species (Chlorophyta, Scenedesmaceae). - Algol. Stud. 105: 51-78.

Hegewald, E.; Engelberg, K. \& Paschma, R. (1988): Beitrag zur Taxonomie der Gattung Scenedesmus, subgenus Scenedesmus (Chlorophyceae). - Nova Hedwigia 47: 497-533.

Hegewald, E.; Krienitz, L. \& Schnepf, E. (1994): Studies on Scenedesmus costato-granulatus SKUJA. - Nova Hedwigia 59: 97-127.

Hegewald, E.; Schmidt, A.; Braband, A. \& Tswerenko, P. (2005): Revision of the Desmodesmus (Sphaeropleales, Scenedesmaceae) species with lateral spines. 2. The multi-spined to spineless taxa. - Algol. Stud. 116 (Arch. Hydrobiol.Suppl. 157): 1-38.

Hegewald, E. \& Schnepf, E. (1979): Geschichte und Stand der Systematik der Grünalgengattung Scenedesmus. - Schweiz. Z. Hydrol. 40: 320-343.

Hegewald, E.; Krienitz, L. \& Schnepf, E. (1994): Studies on Scenedesmus costato-granulatus SKuJA. - Nova Hedwigia 59: 97-127.

Hegewald, E. \& Wolf, M. (2003): Phylogenetic relationships of Scenedesmus and Acutodesmus (Chlorophyta, Chlorophyceae) as inferred from 18S rDNA and ITS-2 sequence comparisons. - Plant Systematics and Evolution 241: 185-191.

Hegewald, E.; Wolf, M.; Keller, A.; Friedl, T. \& KrieniTZ, L. (2010): ITS2 sequence-structure phylogeny in the Scenedesmaceae with special reference to $\mathrm{Co}$ elastrum (Chlorophyta, Chlorophyceae), including the new genera Comasiella and Pectinodesmus. Phycologia 49: 325-335.

Hortobágyi, T. (1971): Új Scenedesmusok a Budapesti Vízmúvek medencéiból (New Scenedesmus from the reservoirs of the Budapest Water Works). - Biológiai Közlemények 19: 23-32.

Jeon, S.L. \& Hegewald, E. (2006): A revision of the species Desmodesmus perforatus and D. tropicus (Chlorophyta, Chlorococcales, Scenedesmaceae). - Phycologia 45: 567-584.

Kessler, E.; Schaefer, M.; Huemmer, C.; Kloboucek, A. \& Huss, V.A.R. (1997): Physiological, biochemical, and molecular characters for the taxonomy of the subgenera of Scenedesmus (Chlorococcales, Chlorophyta) - Bot. Acta 110: 244-250 
KitschKe, M. (2001): Molekulargenetische Untersuchungen zur Diversität und Phylogenie von kokkalen Grünalgen (Scenedesmaceae, Chlorophyta - Chlorophyceae) [Ms thesis]. - 136 pp., Faculty of Biology, University of Göttingen.

KomÁReK, J. \& Ludvík, J. (1972): Die Zellwandstruktur als taxonomisches Merkmal in der Gattung Scenedesmus. 2. Taxonomische Auswertung der untersuchten Arten. - Arch. Hydrobiol./Suppl. 41, Algol. Stud. 6: $11-47$.

KoMÁREK J. \& RuŽIČKA J. (1969): Effect of temperature on the growth and variability of Scenedesmus quadricauda (Turp.) Breb. - In: FotT, B. (ed.): Studies in Phycology. - pp. 262-292, Publ. House Czech. Akad. Sci., Praha.

Korn, R. W. (1969): Nutrition of Cosmarium turpinii. Physiologia Plantarum 22: 1158-1165.

LeY, S.-H. (1947): Heleoplanktonic algae of North Kwangtung. - Botanical Bulletin of the Academia Sinica, Shanghai 1: 270-282.

Markert, S. M.; Müller, T.; Koetschan, C.; Friedl, T. \& Wolf, M. (2012): 'Y' Scenedesmus (Chlorophyta, Chlorophyceae): the internal transcribed spacer 2 rRNA secondary structure re-revisited. - Plant Biology 14: 987-996.

Meyen, F. J. F. (1829): Beobachtungen über einige niedere Algenformen. - Verhandl. Kais. Leop.-Carol. Akad. Naturf. 14: 769-778.

Paschma, R. \& Hegewald, E. (1986): DNA base composition within the genus Scenedesmus (Chlorophyta). - Plant Syst. Evol. 153: 171-180

Pickett-Heaps, J. D. \& Staehelin, L. A. (1975): The ultrastructure of Scenedesmus (Chlorophyceae). II. Cell division and colony formation. - Journal of Phycology 11: 186-202.

Soeder, C. J.; Schulze, G. \& Thiele, D. (1967): Einfluß verschiedener Kulturbedingungen auf das Wachstum in Synchronkulturen von Chlorella fusca $\mathrm{SH}$. et KR. Arch. Hydrobiol./Suppl. 33: 127-171.

Tsarenko, P.; Hegewald, E. \& Braband, A. (2006 “2005”): Scenedesmus-like algae of Ukraine. 1. Diversity and rare taxa from water bodies in Volyn Polissia. - Arch. Hydrobiol./Suppl. 160, Algol. Stud. 118: 1-45.

Tsarenko, P.M. \& PetLevanny, O.A. (2001): Addition to the diversity of algae of Ukraine. - Algologia, Supplement: $1-130$

Turpin, M. P. J. F. (1820) (1816-1829): Dictionnaire des Sciences Naturelles. Planches. 2. Partie: Règne organisé. - pp 1-4, Paris

TuRPIN, P. J. F. (1828): Apercu organographique sur le nombre deux, considéré comme multiplicateur de quatre, huit, douze, seize, trentedeux et soixante-quatre dans la structure des végétaux d'un ordre inférieur ... Mém. Mus. Nat. Hist. Nat. (Paris) 16: 295-344.

Van Hannen E. J.; Fink P. \& Luerling M. (2002): A revised secondary structure model for the internal transcribed spacer 2 of the green algae Scenedesmus and Desmodesmus and its implication for the phylogeny of these algae. - Europ. J. Phycol. 37: 203-208.

Venkataraman, G. S. (1969): The cultivation of algae. -319 p, New Delhi.

WeSt, G.S. (1914): A contribution to our Knowledge of the freshwater algae of Columbia. - Mém. Soc. Neuchâtel. Sci. Nat.5: 1013-1051.

Wynne, M.J. \& Hallan, J.K. (1916): Reinstatement of Tetra- desmus G. M. Smith (Sphaeropleales, Chlorophyta). - Feddes Repertorium 126: 83-86.

Yamagishi, T. \& Hegewald, E. (1998): Scenedesmus curvatocornis PROŠKINA-LAVRENKO var. curvatocornis. - In: Yamagishi, T. \& Akiyama, M. (eds): Photomicrographs of the freshwater algae 20: 58.

Supplementary material

the following supplementary material is available for this article:

Table S1. List of strains, locality of origin and GenBank number.

Table S2. Size measurements of cultured strains.

Table S3. Pairwise comparison of the strains of the serie Desmodesmus.

Table S4. Key for LM characteristics for Subsection Desmodesmus.

Table S5. Key for EM characteristics.

Table S6. Key for ITS-2 characteristics. Numbering of bases see Fig. S1.

Fig. S1. Differences in ITS-2 base composition between $D$. communis strain Hegewald 1974-35 and all strains of D. rectangularis.

Fig. S2. Differences in ITS-2 base composition between $D$. communis strain Hegewald 1974-35 and all strains of D. protuberans et var.: (1-5) D. protuberans var. protuberans, (1) Hegewald 2000-1, (2) Hegewald 1971-23, (3) Hegewald 1996-10, (4) AICB 141, (5) RMUO8; (6-13) D. protuberans var. communioides, (6) CCALA 464, (7) Hegewald 1997-2, (8) UTEX 76, (9) EH 50, (10) ET93, (11) EH 52, (12) EH 84, (13) ET 85. Base exchanges in one strain only were neglected.

Fig. S3. Differences in ITS-2 base composition between $D$. communis strain Hegewald 1974-35 and all strains of D. pseudocommunis and its f. verrucosus.

Fig. S4. Differences in ITS-2 base composition between $D$. communis strain Hegewald 1974-35 and all strains of D. pseudoprotuberans.

Fig. S5. Differences in ITS-2 base composition between $D$. communis strain Hegewald 1974-35 and two strains of D. schmidtii.

Fig. S6. Differences in ITS-2 base composition between $D$. communis strain Hegewald 1974-35 and all other taxa of the series Desmodesmus.

This material is available as part of the online article (http:/ fottea.czechphycology.cz/contents)

(C) Czech Phycological Society (2017)

Received June 12, 2016

Accepted January 2, 2017 